\title{
Experimental study of liquid immiscibility in the Kiruna-type Vergenoeg iron-fluorine deposit, South Africa
}

\author{
Tong Hou ${ }^{\mathrm{a}, \mathrm{b}, *}$, Bernard Charlier ${ }^{\mathrm{a}, \mathrm{c}}$, Olivier Namur ${ }^{\mathrm{a}, \mathrm{c}}$, Philip Schütte ${ }^{\mathrm{d}}$, \\ Ulrich Schwarz-Schampera $^{\mathrm{d}}$, Zhaochong Zhang ${ }^{\mathrm{b}}$, Francois Holtz ${ }^{\mathrm{a}}$ \\ ${ }^{a}$ Leibniz University Hannover, Institute of Mineralogy, Hannover 30167, Germany \\ ${ }^{\mathrm{b}}$ State Key Laboratory of Geological Process and Mineral Resources, China University of Geosciences, Beijing 100083, China \\ ${ }^{\mathrm{c}}$ Department of Geology, University of Liege, 4000 Sart Tilman, Belgium \\ ${ }^{\mathrm{d}}$ Federal Institute for Geosciences and Natural Resources (BGR), Stilleweg 2, Hannover 30655, Germany
}

Received 26 August 2016; accepted in revised form 10 January 2017; Available online 23 January 2017

\begin{abstract}
In this study we experimentally assess whether the bulk composition of the Kiruna-type iron-fluorine Vergenoeg deposit, South Africa (17 wt. $\% \mathrm{SiO}_{2}$ and $55 \mathrm{wt} . \% \mathrm{FeO}_{\text {tot }}$ ) could correspond to an immiscible Fe-rich melt paired with its host rhyolite. Synthetic powder of the host rhyolite was mixed with mafic end-members (ore rocks) in variable proportions. Experimental conditions were $1-2 \mathrm{kbar}$ and $1010^{\circ} \mathrm{C}$, with a range of $\mathrm{H}_{2} \mathrm{O}$ and $\mathrm{F}$ contents in the starting compositions. Pairs of distinct immiscible liquids occur in experiments saturated with fluorite, under relatively dry conditions, and at oxygen fugacity conditions corresponding to FMQ-1.4 to FMQ+1.8 (FMQ = fayalite-magnetite-quartz solid buffer). The Si-rich immiscible liquids contain $60.9-73.0$ wt. $\% \mathrm{SiO}_{2}, 9.1-12.5$ wt. $\% \mathrm{FeO}_{\text {tot }}, 2.4-4.2$ wt. $\% \mathrm{~F}$, and are enriched in $\mathrm{Na}_{2} \mathrm{O}, \mathrm{K}_{2} \mathrm{O}$ and $\mathrm{Al}_{2} \mathrm{O}_{3}$. The paired Fe-rich immiscible melts have 41.0-49.5 wt.\% $\mathrm{SiO}_{2}, 20.6-36.1 \mathrm{wt} . \% \mathrm{FeO}_{\text {tot }}$ and 4.5-6.0 wt.\% F, and are enriched in $\mathrm{MgO}, \mathrm{CaO}$ and $\mathrm{TiO}_{2}$. Immiscibility does not develop in experiments performed under water-rich $\left(\mathrm{aH} \mathrm{H}_{2} \mathrm{O}>0.2 ; \mathrm{a}=\mathrm{activity}\right)$ and/or oxidized $(>F M Q+1.8)$ conditions. In all experiments, solid phases are magnetite, \pm fayalite, fluorite and tridymite. Our results indicate that the rocks from the Vergenoeg pipe crystallized in a magma chamber hosting two immiscible silicate melts. Crystallization of the pipe from the Fe-rich melt explains its extreme enrichment in $\mathrm{Ca}, \mathrm{F}$ and $\mathrm{Fe}$ compared to the host rhyolitic rocks. However, its low bulk silica content compared to experimental Fe-rich melts indicates that the pipe formed by remobilization of a mafic crystal mush dominated by magnetite and fayalite. Segregation of evolved residual liquids as well as the conjugate immiscible Si-rich melt produced the host rhyolite. The huge amount of fluorine in Vergenoeg ores ( $\sim 12 \mathrm{wt} . \%$ F) can hardly be explained by simple crystallization of fluorite from the Fe-rich silicate melt (up to 6 wt.\% F at fluorite saturation). Instead, we confirm a previous hypothesis that the fluorite enrichment is, in part, due to the migration of hydrothermal fluids.
\end{abstract}

(C) 2017 Elsevier Ltd. All rights reserved.

Keywords: Vergenoeg; Liquid immiscibility; Kiruna-type; Silicate melt; Iron-fluorine deposit

\section{INTRODUCTION}

Kiruna-type iron oxide ( \pm apatite) deposits occur in a number of locations across the world. They range in age from Proterozoic to Holocene, and are associated with volcanic rocks or sub-volcanic intrusions (Frietsch, 1978;

\footnotetext{
* Corresponding author at: Leibniz University Hannover, Institute of Mineralogy, Callinstr. 3, 30167 Hannover, Germany.

E-mail addresses: t.hou@mineralogie.uni-hannover.de, thou@cugb.edu.cn (T. Hou).
}

Hitzman et al., 1992; Nystrom and Henriquez, 1994; Dill, 
2010). Controversy persists regarding the genesis of these enigmatic deposits that are dominated by sulfide-poor mineral assemblages (magnetite/hematite, \pm fluorapatite, \pm fayalite, \pm fluorite) and range in size from large bodies (thousands of meters in scale) containing billions of tons of iron ore, to small veins and veinlets (Hildebrand, 1986; Williams et al., 2005). The Kiruna-type deposits have been interpreted to have an exhalative-synsedimentary origin (Parak, 1975), or to have formed by epigenetichydrothermal processes (Gleason et al., 2000; Dare et al., 2014a). 'Kiruna-type' deposits are often considered as an end-member of the hydrothermal Iron Oxide-CopperGold 'IOCG' group (Hitzman et al., 1992; Hitzman, 2000). Magmatic processes are also commonly invoked to explain the formation of Kiruna-type deposits due to magmatic oxygen and iron isotope ratios (Jonsson et al., 2013; Bilenker et al., 2016). Processes typically proposed include formation and stagnation of a volatile-bearing $\mathrm{Fe}$-rich immiscible melt (e.g. Naslund et al., 2002; Chen et al., 2010; Tornos et al., 2016; Velasco et al., 2016) followed by fractional crystallization, and formation of magnetiterich cumulate rocks (Knipping et al., 2015a). Melt inclusions in plagioclase phenocrysts from andesite hosts of Chilean deposits are dominated by silica-rich melts with droplets of immiscible iron-rich melt. These confirm the likely role of silicate liquid immiscibility in the formation of Kiruna-type deposits (Tornos et al., 2016). The magmatic stage in the formation of Kiruna-type deposits is firmly suggested by the presence of volcanic textures and structures such as magmatic flows, vesicular structures and volcanic bombs (Naslund et al., 2002; Nyström et al., 2008; Knipping et al., 2015a). The extent to which hydrothermal fluids played a role in remobilizing iron in Kiruna deposits is however more debated. Accurate constraints on this issue are complicated by the comparatively small effect of post-mineralization metasomatism on the $\mathrm{Fe}$ isotope signature compared to its effect on the $\mathrm{O}$ isotope signature (Childress et al., 2016). However, it is known that metasomatism strongly affects critical elements, promotes the exsolution of REE-phosphates within apatite grains and can alter the $\mathrm{F} / \mathrm{Cl}$ ratio of apatite (Harlov et al., 2016; Jonsson et al., 2016). Fluids may also affect the redistribution of some elements such as F, S and P (e.g. Harlov et al., 2002; Knipping et al., 2015a,b).

The Vergenoeg deposit ( 1.95 Ga; Crocker, 1985) in South Africa is a Kiruna-type massive iron oxide deposit (Borrok et al., 1998), characterized by a high content of fluorite. It is currently mined and accounts for $3.4 \%$ of the total world production of fluorine (Graupner et al., 2015) with a fluorite resource in excess of 174 million tons at 28.1 wt. \% $\mathrm{CaF}_{2}$ (Fourie, 2000). Three contrasting genetic models have been proposed for Vergenoeg: (1) the separation of an immiscible Fe-rich liquid, i.e. Fe-rich mafic melt from the conjugate granitic (rhyolitic) magma (Crocker, 1985); (2) combined magmatic and hydrothermal activity leading to the extensive alteration of the primary fayalitefluorite-ilmenite assemblage (Borrok et al., 1998; Fourie, 2000), and (3) the development of a fluorine-rich endmember of the iron oxide copper-gold (IOCG) group associated with carbonatites, in particular the Phalaborwa car- bonatite of similar age (ca. 2.05 Ga, Goff et al., 2004). The origin of the Vergenoeg deposit is therefore highly controversial, as is the origin of the large amounts of fluorite observed in the deposit. $\mathrm{Rb}-\mathrm{Sr}$ and $\mathrm{Sm}-\mathrm{Nd}$ isotopic ratios of fluorite crystals indicate that a significant proportion of these crystals formed from magmas (Kinnaird et al., 2004; Graupner et al., 2015) but fluid inclusion analyses also suggest that some fluorite crystals formed from hydrothermal fluids (Borrok et al., 1998).

With this study, we aim to better understand the magmatic stages in the formation of the Vergenoeg deposit, and specifically test the hypothesis that silicate liquid immiscibility formed a rhyolitic melt and a conjugate iron-rich silicate melt. We experimentally assess whether the bulk composition of the ore body and the host rhyolite could represent a pair of immiscible melts in equilibrium. We investigate the role of volatiles (fluorine and $\mathrm{H}_{2} \mathrm{O}$ ) in the development of immiscibility and saturation of fluorite in immiscible melts. Based on our new experimental data, we propose that the Vergenoeg pipe represents the cumulates from an immiscible Fe-rich melt which was saturated in fluorite. We also confirm that hydrothermal fluids contributed to the high fluorine content of the Vergenoeg deposit.

\section{GEOLOGY OF THE VERGENOEG DEPOSIT}

The Vergenoeg deposit is situated in the center of the Bushveld Complex in South Africa. The Bushveld Complex intruded sedimentary and volcanic rocks of the Transvaal Sequence (Eriksson et al., 1995), within the Kaapvaal Craton. These host rocks belong to the Rooiberg Group rhyolite (Hatton and Schweitzer, 1995; Buchanan et al., 2004). The Rooiberg Group is divided into four formations comprising the lower Dullstroom and Damwal Formations and the upper Kwaggasnek and Schrikkloof Formations (Schweitzer et al., 1995; Mathez et al., 2013) with a total thickness of 3-5 km (Twist and French, 1983; Schweitzer et al., 1995). The Dullstroom Formation (61-78 wt.\% $\mathrm{SiO}_{2}$ ) includes interbedded basaltic, andesitic, dacitic and rhyolitic flows and becomes richer in silica with increasing stratigraphic height. The Damwal Formation is dominated by dacite to low-silica rhyolite $\left(\sim 68 \mathrm{wt} . \% \mathrm{SiO}_{2}\right)$ while the Kwaggasnek ( $\sim 72$ wt. $\left.\% \mathrm{SiO}_{2}\right)$ and Schrikkloof ( 74 wt.\% $\mathrm{SiO}_{2}$ ) Formations are rhyolites (Schweitzer and Hatton, 1995; Schweitzer et al., 1995; Buchanan et al., 1999; 2002). The Vergenoeg deposit consists of a vertical, discordant, igneous pipe emplaced in rhyolites and pyroclastic rocks (Schweitzer et al., 1995; Fig. 1). The pyroclastic succession is commonly referred to as the Vergenoeg Pyroclastic Rock Suite (Crocker, 1985).

\subsection{The Vergenoeg pipe}

The Vergenoeg pipe has an oval shape at the surface with a north-south extension of $900 \mathrm{~m}$ and an east-west diameter of $\sim 600 \mathrm{~m}$ (Fig. 1; Goff et al., 2004). The shape of the pipe below the surface has been investigated using geophysical methods (gravity surveys) as well as drill core mapping. The body of the pipe appears to have a funnel 

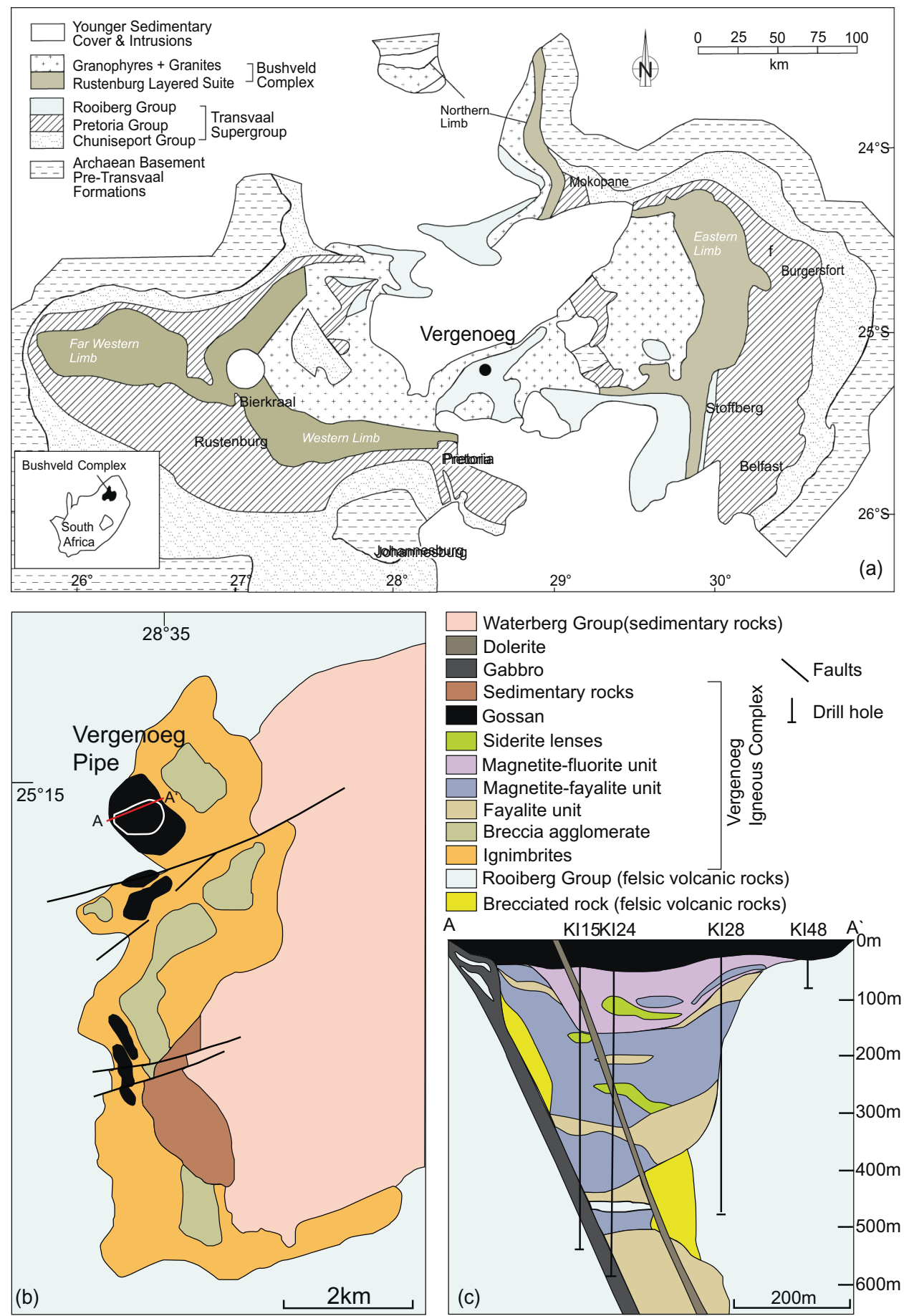

Fig. 1. (a) Simplified geological map of the Bushveld Complex (modified after Barnes and Maier, 2002); Geological overview (b) and a crosssection (c) of the Vergenoeg deposit (modified after Goff et al., 2004), showing the distribution of the lithological units and the position of the drill cores. The samples used in this study are from the open pit and the drill core KI24. See Appendix for details.

shape (depth >650 m; Crocker, 1985). Similar pipe-like morphologies have been described for several other Kiruna-type and related deposits (e.g. the Pea Ridge deposit in USA; Harlov et al., 2016).

The Vergenoeg pipe consists of three gradational hypogene units of magnetite-fluorite, magnetite-fayalite and fayalite. The contacts between the pipe and the surrounding rocks are highly variable in terms of mineralogy. Some zones have sharp contacts with little alteration of the felsic wall rocks, whereas other areas have strongly altered wall rocks with Fe-rich sericite and epidote locally observed (Goff et al., 2004). Both massive and disseminated fluorites occur throughout the pipe, with decreasing abundance towards greater depths. 
The upper part of the pipe is made up of gossan (ca. $50 \mathrm{~m}$ thick). It was formed by weathering of magnetitefluorite rocks through oxidation and hydration of magnetite, iron sulfides and siderite into hematite and goethite (Borrok et al., 1998). Within the gossan, three types of ore can be distinguished: (1) high-grade, massive, specularitic hematite ore $\left(60 \mathrm{wt} . \% \mathrm{Fe}_{2} \mathrm{O}_{3}\right)$; (2) mixed fluoritehematite/goethite ore forming the bulk of the gossan; and (3) high-grade fluorite ore (60 wt.\% $\mathrm{CaF}_{2}$; Crocker, 1985) in veins and brecciated plugs rich in fluorite, with associated siderite and magnetite (Fig. 2). The presence of preserved fluorite veins of metspar provides clear evidence for alteration of the host rock to gossan. They are usually vertical and locally merge to form plugs of fluorite-rich rock with veins of siderite and magnetite (Crocker, 1985).

The magnetite-fluorite unit $(\sim 100 \mathrm{~m}$ thick $)$ is the main fluorite ore resource at Vergenoeg (Goff et al., 2004). The fluorite content decreases from $32 \mathrm{vol} . \%$ at the top to
20 vol. $\%$ at the bottom (Fourie, 2000). Coarse-grained fluorite and magnetite crystals are set in a groundmass of magnetite, fluorite and siderite with accessory REE minerals (Goff et al., 2004). At a depth of about $150 \mathrm{~m}$, there is a gradational change into the magnetite-fayalite unit that represents a transition zone between the magnetite-fluorite unit and the deeper fayalite unit. Rocks of the magnetitefayalite unit are composed of fayalite, magnetite and interstitial fluorite. The lowermost fayalite unit of the Vergenoeg pipe is almost exclusively made up of unaltered, coarsegrained, prismatic fayalite $(>90 \mathrm{vol} . \%)$ with rare fluorite and apatite.

\subsection{The Vergenoeg Pyroclastic Rock Suite (VPS)}

Pyroclastic rocks associated with the Vergenoeg pipe discordantly overlie the uppermost flow-banded Rooiberg Group rhyolites, i.e. Schrikkloof Formation (Crocker
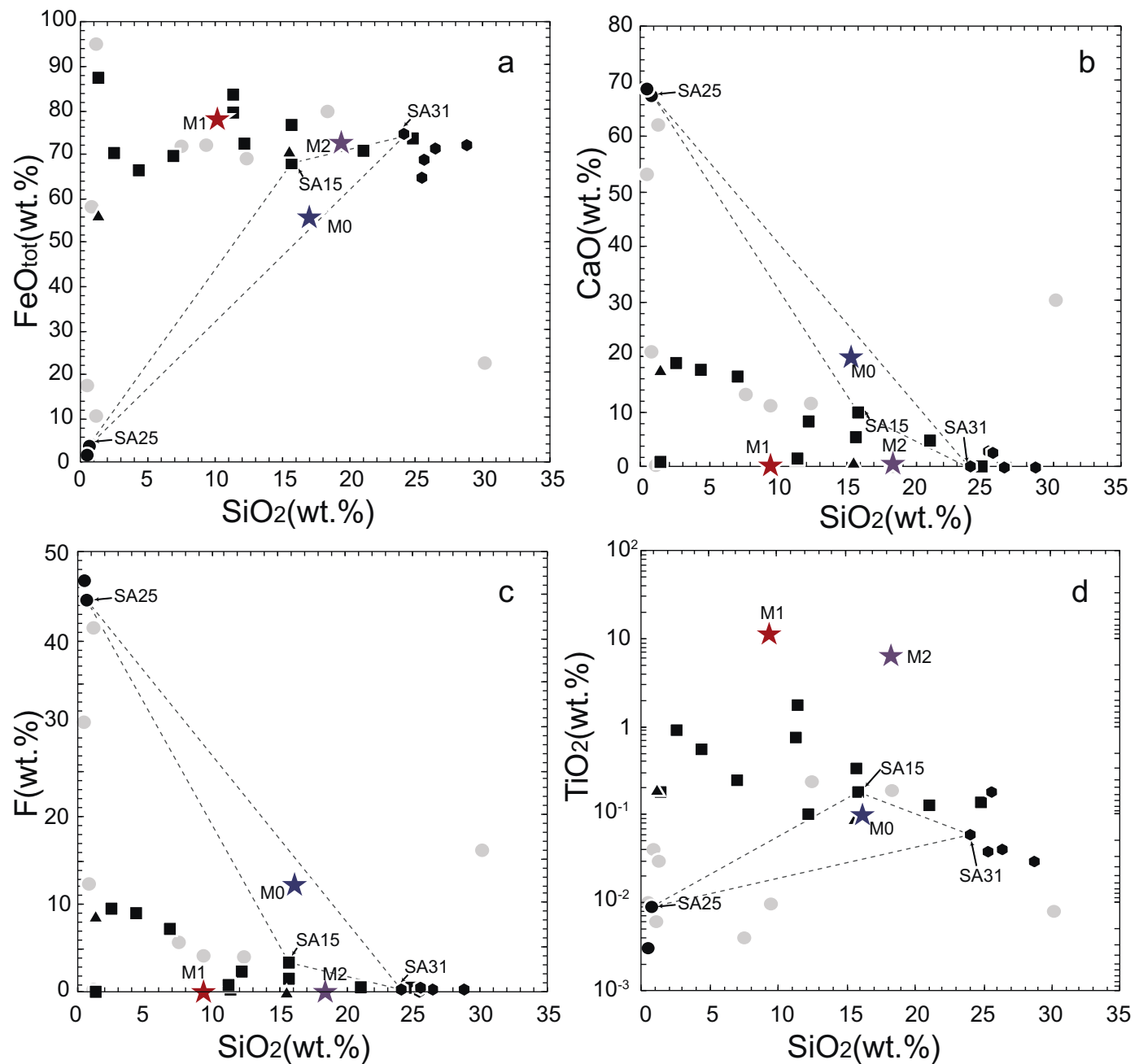

gossan rocks - fayalite unit magnetite-fayalite unit

^ magnatite-fluorite unit $\bullet$ fluorite ore $\star \mathrm{M} 0 \star \mathrm{M} 1 \star \mathrm{M} 2$

Fig. 2. Harker diagrams illustrating the compositional range of rocks from the Vergenoeg pipe (Appendix). M0 is calculated by mixing $40 \mathrm{wt}$. $\%$ SA 15 with $40 \mathrm{wt} . \%$ SA31 and $20 \mathrm{wt} . \%$ SA25, and represents the estimated average bulk composition of the pipe. M1 and M 2 are mixed from $30 \mathrm{wt} . \%$ fayalite and $70 \mathrm{wt} . \%$ magnetite, and $60 \mathrm{wt} . \%$ fayalite and $40 \mathrm{wt} . \%$ magnetite, respectively. 
et al., 2001). Two units are distinguished within the pyroclastic rocks. The basement is formed by siliceous rocks and welded agglomerate, laterally grading into a finegrained tuff with increasing distance from the pipe (Crocker, 1985). The thickness of this unit reaches $60 \mathrm{~m}$, a local maximum. It is commonly referred to as the basal felsite (Borrok et al., 1998) but can be genetically referred to as an ignimbrite (Fig. 1; Fourie, 2000). Borrok et al. (1998) suggested that the basal felsites might also represent a certain facies of the Rooiberg Group rhyolites (Mathez et al., 2013). The basal felsites are overlain by a $40 \mathrm{~m}$ thick volcanic breccia (Fig. 1), consisting of partly rounded felsic clasts in a fine-grained ferruginous-felsic matrix, interlayered with a hematite tuff (Fourie, 2000). The upper part of the succession is formed by $10 \mathrm{~m}$ of sedimentary rocks consisting of pyroclastic detritus and alternating layers of hematite and felsite (Crocker, 1985; Fourie, 2000).

\section{EXPERIMENTAL AND ANALYTICAL PROCEDURES}

\subsection{Initial hypothesis and methodology}

The formation of the Vergenoeg deposit was previously attributed to a silicate-liquid immiscibility process by Crocker (1985). In this model, the basal felsites of the VPS constitute the extrusive equivalent of an immiscible Si-rich end-member whereas the Vergenoeg pipe is the conjugate Fe-rich end-member. The corollary of this hypothesis is that the weighted sum of the silicic host rocks and the iron ore body, possibly in combination with variable amounts of volatiles $\left(\mathrm{H}_{2} \mathrm{O}, \mathrm{S}, \mathrm{F}\right.$ and $\left.\mathrm{Cl}\right)$, represents the composition of the original parent ore-bearing magma prior to immiscibility. To test the hypothesis of immiscibility we do not require the exact relative proportions of the two end-members as the compositions of immiscible pairs define a locus between which immiscibility develops. Any composition that plots on the mixing trend between the equilibrium immiscible pairs would unmix, with the proportions of the two conjugate liquids determined by the lever rule.

As stated above, the Vergenoeg pipe shows significant mineralogical and geochemical variations with depth and is also laterally heterogeneous (Fig. 1). In order to obtain a representative (average) bulk composition of the pipe, it is necessary to use a mixture of sample compositions from various units of the pipe. We sampled fresh fluorite ore, magnetite-fayalite and magnetite-fluorite rocks from KI 24 drill core, and gossan rocks in the open pit (Fig. 1 and see details in Supplementary Table 1). After screening under the microscope, fresh samples were selected, sawed into slabs, and the central parts were used for whole-rock analyses. Specimens were crushed in a steel mortar and ground to powder in a steel mill. Loss on ignition was determined gravimetrically after heating the samples at $1030{ }^{\circ} \mathrm{C}$ for $15 \mathrm{~min}$. Major element analyses (Supplementary Table 1) were performed on fused glass discs using a scanning wavelength dispersion X-ray fluorescence (XRF) spectrometer at BGR in Hannover. In-house standards and 130 certified reference materials were used for calibration and assessment of accuracy. The analytical uncertainties are typically less than $1 \%$ as estimated by repeated analyses of international standards, which were not used in the development of the calibration curves for the XRF.

Magnetite-fayalite and fayalite units constitute the dominant facies of the Vergenoeg pipe (Fig. 1); fluorite contents are variable but, on average, relatively high (Fig. 2). Average $\mathrm{F}$ content is $6.70 \mathrm{wt} . \%$ in the magnetite-fayalite unit and $0.9 \mathrm{wt} . \%$ in the fayalite unit. Based on volume consideration of the deposit, we assume that the Vergenoeg pipe consists of $40 \%$ magnetite-fayalite unit, $40 \%$ fayalite unit and $20 \%$ fluorite ores. Based on these values, we prepared mafic end-members for the experiments using two approaches (Fig. 2): (1) we mixed the natural samples SA15 (magnetite-fayalite unit), SA31 (fayalite unit) and SA25 (massive fluorite) in a ratio of 0.4:0.4:0.2 (composition M0; Table 1); (2) we prepared synthetic mafic compositions by mixing synthetic oxides according to the compositions of mineral end-members: composition M1 (30 wt. $\%$ fayalite $+70 \mathrm{wt} . \%$ magnetite) and composition M2 (60 wt. $\%$ fayalite +40 wt. $\%$ magnetite) to which we added variable amounts of fluorite (Table 2). The average mineral compositions of fayalite and magnetite are from Borrok et al. (1998).

Abundant studies have been conducted on the felsic rocks in the Bushveld Complex (e.g. Hatton and Schweitzer, 1995; Mathez et al., 2013). Using previous studies, we prepared two rhyolitic glasses representative of the felsic end-members (Fig. 3): F1 is representative of the average composition of the rhyolite of the Schrikkloof Formation, whereas F2 is the average composition of the felsic (i.e. rhyolitic) rocks from Dullstroom, Schrikkloof and Kwaggasnek Formations. F1 has a higher concentration of $\mathrm{K}_{2} \mathrm{O}$ whereas $\mathrm{F} 2$ has a higher $\mathrm{FeO}_{\text {tot }}$ concentration.

\subsection{Preparation of starting materials}

For the natural mafic end-member, powdered samples of SA15, SA31 and SA25 were mixed together in ethanol. For the synthetic mafic end-members we mixed highpurity commercially purchased oxide powders $\left(\mathrm{SiO}_{2}\right.$, $\mathrm{TiO}_{2}, \mathrm{Al}_{2} \mathrm{O}_{3}, \mathrm{Fe}_{2} \mathrm{O}_{3}, \mathrm{MnO}$ and $\mathrm{MgO}$ ). Synthetic and natural dry starting materials were homogenized in an agate planetary ball mill for a minimum of $2 \mathrm{~h}$.

For the felsic compositions we mixed high-purity oxides and carbonates and homogenized the powders in an agate planetary ball mill. The powder mixture was then melted in a Pt crucible at $1600{ }^{\circ} \mathrm{C}$ (atmospheric oxygen fugacity; $f \mathrm{O}_{2}$ ) for $3 \mathrm{~h}$. The rhyolitic glass was then ground in a steel mortar (to a grain size $<2 \mathrm{~mm}$ ) and re-melted in the furnace $\left(1600{ }^{\circ} \mathrm{C}, 3.5 \mathrm{~h}\right)$ in order to homogenize the material and to promote complete degassing of $\mathrm{CO}_{2}$. After quenching, parts of the glasses were separated, mounted in epoxy, polished and analyzed by electron microprobe (F1 and F2 in the Table 1).

The starting materials for experiments were produced by mixing mafic end-members (M0, M1 and M2) and felsic end-members (F1 and F2) in specific proportions (Table 2). In some experiments, deionized water was added to the starting material (see the column $\mathrm{H}_{2} \mathrm{O}$ in Table 2). In exper- 
Table 1

Compositions of end-members used for the preparation of starting compositions (wt.\%).

\begin{tabular}{|c|c|c|c|c|c|c|c|c|c|c|c|c|c|}
\hline & $\mathrm{SiO}_{2}$ & $\mathrm{TiO}_{2}$ & $\mathrm{Al}_{2} \mathrm{O}_{3}$ & $\mathrm{FeO}_{\text {tot }}$ & $\mathrm{MnO}$ & $\mathrm{MgO}$ & $\mathrm{CaO}$ & $\mathrm{Ca}$ & $\mathrm{Na}_{2} \mathrm{O}$ & $\mathrm{K}_{2} \mathrm{O}$ & $\mathrm{P}_{2} \mathrm{O}_{5}$ & $\mathrm{~F}$ & Total \\
\hline$\overline{\mathrm{M} 0}$ & 17.10 & 0.11 & 0.14 & 55.39 & 0.79 & 0.31 & & 13.37 & $<0.01$ & 0.01 & 0.00 & 12.79 & 100.06 \\
\hline M1 & 10.18 & 11.15 & 0.18 & 77.32 & 0.89 & 0.27 & & & & & & & 99.94 \\
\hline M2 & 19.36 & 6.34 & 0.14 & 72.43 & 1.36 & 0.36 & & & & & & & 99.92 \\
\hline $\mathrm{F} 1$ & 75.98 & 0.2 & 11.53 & 2.98 & 0.06 & 0.54 & 0.25 & & 2.42 & 6.00 & & & 99.96 \\
\hline $\mathrm{F} 2$ & 75.26 & 0.31 & 11.87 & 3.62 & 0.14 & 0.77 & 0.79 & & 2.35 & 4.98 & 0.05 & & 100.14 \\
\hline
\end{tabular}

$\mathrm{Ca}$ is dominantly under the form of $\mathrm{CaF}_{2}$ in $\mathrm{M} 0$ and is therefore not stated as $\mathrm{CaO}$.

iments using synthetic mafic starting compositions (M1 and $\mathrm{M} 2$ ), we also added fluorine (as $\mathrm{CaF}_{2}$ ) in varying amounts.

\subsection{Experimental conditions and methods}

According to Buchanan et al. (2004) the maximum thickness of the Rooiberg Group within the Transvaal Basin is approximately $6 \mathrm{~km}$. A magma chamber situated at the base of the Rooiberg Group would therefore attain a maximum pressure of about 2 kbars. Kleemann and Twist (1989) suggest that the nearby coeval granite was emplaced at a high level and estimated a pressure of about $1 \mathrm{kbar}$ during the crystallization of the upper part of the granite intrusion based on a $3 \mathrm{~km}$ thick cover of Rooiberg Group felsites. Consequently, a pressure of $1 \mathrm{kbar}$ was chosen for most experiments but several were run at $2 \mathrm{kbars}$.

The experiments were performed in internally heated pressure vessels (IHPV), at the Institute of Mineralogy, Leibniz Universität Hannover (Berndt et al., 2002). Experimental conditions are summarized in Table 3. Pressure was monitored continuously with an uncertainty of about 1 bar. Temperature was measured with four S-type $\left(\mathrm{Pt}-\mathrm{Pt}_{90} \mathrm{Rh}_{10}\right)$ thermocouples to control the temperature gradient over a length of $\sim 30 \mathrm{~mm}$ inside the vessel. Temperature oscillations were below $3-5^{\circ} \mathrm{C}$ depending on the vessel and the experimental run. Rapid quench $\left[150^{\circ} \mathrm{C} / \mathrm{s}\right.$; Berndt et al. (2002)] was performed at the end of the runs. Experiments were performed at the intrinsic $f \mathrm{O}_{2}$ of the vessel or at controlled $f \mathrm{O}_{2}$. For experiments at intrinsic $f \mathrm{O}_{2}$ conditions, we used an autoclave with $\mathrm{Ar}$ as the sole pressure medium. In these experiments, $f \mathrm{O}_{2}$ ranges from $\sim \mathrm{FMQ}$ (fayalitemagnetite-quartz redox equilibrium) in dry conditions to $\mathrm{FMQ}+3.3$ under fluid saturated conditions. Experiments at controlled $f \mathrm{O}_{2}$ were conducted using a vessel equipped with a $\mathrm{H}_{2}$-membrane which allows monitoring and adjustment of the hydrogen pressure $\left(f \mathrm{H}_{2}\right)$ and thus the $f \mathrm{O}_{2}$ inside the vessel. The evolution of $\mathrm{H}_{2}$ pressure $\left(f \mathrm{H}_{2}\right)$ in the vessel was directly measured with the Shaw membrane technique applied at Hannover (Berndt et al., 2002). Experiments were run for 4-500 h (Table 3).

Starting materials were weighed and placed in Au capsules $(20 \mathrm{~mm}$ in length and $2.8 \mathrm{~mm}$ in internal diameter, with a $0.2 \mathrm{~mm}$ wall thickness). One end of each capsule was welded shut before the starting material was inserted. Deionized water was added to some samples (Table 2). Open capsule ends of dry samples were immediately welded shut whereas water-bearing samples were frozen in liquid nitrogen before they were welded shut. This method minimizes the loss of water due to vaporization during welding.
Capsules were weighed after welding and then placed in a dry furnace at $150^{\circ} \mathrm{C}$ for $1-2 \mathrm{~h}$ before they were weighed again, to check for any loss of material. Re-weighing of the capsules after the experimental runs showed identical weights for most capsules indicating that no volatiles were lost during the experiments. Small chips of experimental products (about $2 \mathrm{~mm}$ in diameter) of each sample were prepared as polished thin sections or mounted in epoxy for electron microprobe analyses.

\subsection{Electron microprobe analyses}

The analyses of the experimental products were performed at the Leibniz Universtät Hannover, and at BGR. Both institutes use a Cameca SX100 electron microprobe equipped with five WDS detectors. Operating conditions were set at $15 \mathrm{kV}$ with a $10 \mathrm{nA}$ beam current. We used a focused beam $(1 \mu \mathrm{m})$ for minerals and a defocused beam $(5-20 \mu \mathrm{m})$ for glasses. The peak counting times for glasses were $10 \mathrm{~s}$ for $\mathrm{Si}, \mathrm{Ti}, \mathrm{Al}, \mathrm{Fe}, \mathrm{Mn}, \mathrm{Mg}$ and $\mathrm{Ca}$, and $8 \mathrm{~s}$ for the alkalis. The elements $\mathrm{Na}, \mathrm{K}, \mathrm{Si}, \mathrm{Ca}$ and $\mathrm{Fe}$ were analyzed first. Subsequent analyses of $\mathrm{F}$ were performed using a second set of analytical conditions $(60 \mathrm{nA})$, and the counting time was $120 \mathrm{~s}$ on peak and $60 \mathrm{~s}$ for background. More details on the method used for fluorine measurements can be found in Zhang et al. (2016). For glasses and minerals, we used the following standards for $\mathrm{K} \alpha \mathrm{X}$-ray line calibration: albite for $\mathrm{Na}$, orthoclase for $\mathrm{K}$, wollastonite for $\mathrm{Si}$ and $\mathrm{Ca}, \mathrm{TiO}_{2}$ for $\mathrm{Ti}, \mathrm{Fe}_{2} \mathrm{O}_{3}$ for $\mathrm{Fe}, \mathrm{MgO}$ for $\mathrm{Mg}, \mathrm{Mn}_{3} \mathrm{O}_{4}$ for $\mathrm{Mn}$. Raw data were corrected using the PAP routine (Zhang et al., 2016). The precision for oxide concentrations was better than $1 \%$. No significant alkali loss (within uncertainty) was detected during measurements.

\subsection{Water content in the glass and oxygen fugacity}

The water content of the homogenous glass in sample B0a (the only super-liquidus experiment) was determined by Fourier transform infra-red (FTIR) spectroscopy using the mid-infrared (MIR) range (i.e. wave numbers between 400 and $4000 \mathrm{~cm}^{-1}$ corresponding to wavelengths of 25 $2.5 \mu \mathrm{m})$. We obtained a value of $1.48 \mathrm{wt} . \% \mathrm{H}_{2} \mathrm{O}$. For other samples the water contents were estimated from a combination of microprobe totals (by difference method), and added water and melt proportions (mass balance calculation). The typical error is $0.5 \mathrm{wt} . \% \mathrm{H}_{2} \mathrm{O}$. The water content of sample B0a (1.48 wt.\%), as determined by IR, allowed us to evaluate the accuracy of the 'by-difference' method (e.g., Devine et al., 1995). The calculated value (i.e. $1.0 \pm 0.5$ wt. $\% \mathrm{H}_{2} \mathrm{O}$ ) 
Table 2

Compositions (wt.\%) of starting materials, calculated from weight proportions of natural samples and synthetic glasses.

\begin{tabular}{|c|c|c|c|c|c|c|c|c|c|c|c|c|c|c|c|c|}
\hline & Run & Proportions (wt.\%) & $\mathrm{SiO}_{2}$ & $\mathrm{TiO}_{2}$ & $\mathrm{Al}_{2} \mathrm{O}_{3}$ & $\mathrm{FeO}_{\text {tot }}$ & $\mathrm{MnO}$ & $\mathrm{MgO}$ & $\mathrm{CaO}$ & $\mathrm{Na}_{2} \mathrm{O}$ & $\mathrm{K}_{2} \mathrm{O}$ & $\mathrm{P}_{2} \mathrm{O}_{5}$ & $\mathrm{~F}$ & $\mathrm{~F}_{2} \mathrm{O}_{-1}$ & $\mathrm{H}_{2} \mathrm{O}$ & Total \\
\hline $\mathrm{A} 0 \mathrm{a}$ & exp1 & $60 \% \mathrm{~F} 1+40 \% \mathrm{M} 0$ & 51.99 & 0.17 & 7.28 & 24.00 & 0.31 & 0.47 & 7.47 & 1.53 & 3.46 & & 5.02 & 2.90 & & 99.6 \\
\hline $\mathrm{A} 0 \mathrm{~b}$ & $\exp 2$ & & 51.88 & 0.17 & 7.25 & 24.13 & 0.31 & 0.47 & 7.50 & 1.52 & 3.44 & & 5.03 & 2.91 & & 99.6 \\
\hline $\mathrm{A} 0 \mathrm{c}$ & $\exp 3$ & & 52.21 & 0.17 & 7.27 & 24.97 & 0.32 & 0.47 & 6.61 & 1.53 & 3.45 & & 4.43 & 2.56 & & 99.6 \\
\hline A5a & exp1 & $57 \% \mathrm{~F} 1+38 \% \mathrm{M} 0$ & 49.29 & 0.16 & 6.90 & 22.73 & 0.30 & 0.44 & 7.11 & 1.45 & 3.27 & & 4.77 & 2.76 & 5 & 94.4 \\
\hline A $5 b$ & $\exp 2$ & & 49.43 & 0.16 & 6.91 & 23.04 & 0.30 & 0.44 & 7.04 & 1.45 & 3.28 & & 4.72 & 2.73 & 5 & 94.8 \\
\hline B0a & $\exp 2$ & $75 \% \mathrm{~F} 1+25 \% \mathrm{M} 0$ & 60.29 & 0.18 & 8.98 & 16.48 & 0.20 & 0.51 & 5.01 & 1.89 & 4.28 & & 3.30 & 1.91 & & 99.7 \\
\hline B0b & $\exp 3$ & & 60.23 & 0.18 & 8.95 & 16.79 & 0.20 & 0.51 & 4.86 & 1.89 & 4.26 & & 3.20 & 1.85 & & 99.7 \\
\hline $\mathrm{COa}$ & $\exp 3$ & $35 \% \mathrm{~F} 1+65 \% \mathrm{M} 0$ & 37.30 & 0.15 & 3.95 & 44.97 & 0.60 & 0.42 & 6.23 & 0.82 & 1.85 & & 4.26 & 2.46 & & 99.2 \\
\hline $\mathrm{D} 2 \mathrm{a}$ & exp4 & $58.5 \% \mathrm{~F} 2+39 \% \mathrm{M} 1+0.5 \% \mathrm{CaF}_{2}$ & 47.26 & 4.17 & 6.96 & 33.31 & 0.37 & 0.54 & 0.85 & 1.41 & 2.96 & 0.03 & 0.24 & 0.14 & 2 & 98.0 \\
\hline D4a & exp4 & $57.6 \% \mathrm{~F} 2+38.4 \mathrm{M} 1+0.5 \% \mathrm{CaF}_{2}$ & 46.29 & 4.09 & 6.82 & 32.63 & 0.36 & 0.53 & 0.84 & 1.38 & 2.90 & 0.02 & 0.24 & 0.14 & 4 & 96.0 \\
\hline D6a & exp4 & $56.1 \% \mathrm{~F} 2+37.4 \% \mathrm{M} 1+0.5 \% \mathrm{CaF}_{2}$ & 45.32 & 4.00 & 6.68 & 31.95 & 0.35 & 0.52 & 0.83 & 1.35 & 2.84 & 0.02 & 0.24 & 0.14 & 6 & 94.0 \\
\hline $\mathrm{D} 2 \mathrm{~b}, \mathrm{E} 2 \mathrm{a}$ & exp4-5 & $58.5 \% \mathrm{~F} 2+39 \% \mathrm{M} 2+0.5 \% \mathrm{CaF}_{2}$ & 50.58 & 2.46 & 6.95 & 31.50 & 0.54 & 0.58 & 0.86 & 1.41 & 2.96 & 0.03 & 0.24 & 0.14 & 2 & 98.0 \\
\hline E4a & $\exp 5$ & $57.6 \% \mathrm{~F} 2+38.4 \% \mathrm{M} 2+0.5 \% \mathrm{CaF}_{2}$ & 49.54 & 2.41 & 6.80 & 30.86 & 0.53 & 0.56 & 0.85 & 1.38 & 2.90 & 0.02 & 0.24 & 0.14 & 4 & 96.0 \\
\hline D6b, E6a & exp4-5 & $56.1 \% \mathrm{~F} 2+37.4 \% \mathrm{M} 2+0.5 \% \mathrm{CaF}_{2}$ & 48.50 & 2.36 & 6.66 & 30.21 & 0.52 & 0.55 & 0.84 & 1.35 & 2.84 & 0.02 & 0.24 & 0.14 & 6 & 94.0 \\
\hline $\mathrm{E} 2 \mathrm{~b}$ & exp6 & $57.6 \% \mathrm{~F} 2+38.4 \% \mathrm{M} 2+2.5 \% \mathrm{CaF}_{2}$ & 49.54 & 2.41 & 6.80 & 30.86 & 0.53 & 0.56 & 2.28 & 1.38 & 2.90 & 0.02 & 1.21 & 0.70 & 2 & 98.0 \\
\hline $\mathrm{E} 4 \mathrm{~b}$ & exp6 & $56.1 \% \mathrm{~F} 2+37.4 \% \mathrm{M} 2+2.5 \% \mathrm{CaF}_{2}$ & 48.50 & 2.36 & 6.66 & 30.21 & 0.52 & 0.55 & 2.27 & 1.35 & 2.84 & 0.02 & 1.21 & 0.70 & 4 & 96.0 \\
\hline E6b & exp6 & $54.9 \% \mathrm{~F} 2+36.6 \% \mathrm{M} 2+2.5 \% \mathrm{CaF}_{2}$ & 47.47 & 2.31 & 6.52 & 29.56 & 0.51 & 0.54 & 2.26 & 1.32 & 2.78 & 0.02 & 1.21 & 0.70 & 6 & 94.0 \\
\hline G0a, H0a, I0a & $\exp 7-8-9$ & $75.2 \% \mathrm{~F} 2+18.8 \% \mathrm{M} 2+6 \% \mathrm{CaF}_{2}$ & 59.42 & 1.33 & 8.89 & 17.17 & 0.30 & 0.64 & 4.92 & 1.81 & 3.81 & 0.03 & 2.92 & 1.69 & & 100.0 \\
\hline G0b, H0b, I0b & $\exp 7-8-9$ & $70.4 \% \mathrm{~F} 2+17.6 \% \mathrm{M} 2+12 \% \mathrm{CaF}_{2}$ & 56.89 & 1.27 & 8.51 & 16.43 & 0.29 & 0.61 & 7.77 & 1.74 & 3.64 & 0.03 & 4.88 & 2.82 & & 100.0 \\
\hline G0c, H0c, I0c & $\exp 7-8-9$ & $60.8 \% \mathrm{~F} 2+15.2 \% \mathrm{M} 2+24 \% \mathrm{CaF}_{2}$ & 48.04 & 1.07 & 7.18 & 13.88 & 0.24 & 0.51 & 17.73 & 1.47 & 3.08 & 0.03 & 11.71 & 6.77 & & 100.0 \\
\hline J6a & $\exp 10$ & $70.4 \% \mathrm{~F} 2+17.6 \% \mathrm{M} 2+6 \% \mathrm{CaF}_{2}$ & 55.85 & 1.25 & 8.36 & 16.14 & 0.28 & 0.60 & 4.62 & 1.70 & 3.58 & 0.03 & 2.75 & 1.59 & 6 & 100.0 \\
\hline $\mathrm{J} 6 \mathrm{~b}$ & exp10 & $65.6 \% \mathrm{~F} 2+16.4 \% \mathrm{M} 2+12 \% \mathrm{CaF}_{2}$ & 53.48 & 1.19 & 8.00 & 15.44 & 0.27 & 0.57 & 7.30 & 1.64 & 3.42 & 0.03 & 4.58 & 2.65 & 6 & 100.0 \\
\hline $\mathrm{J} 6 \mathrm{c}$ & $\exp 10$ & $56 \% \mathrm{~F} 2+14 \% \mathrm{M} 2+24 \% \mathrm{CaF}_{2}$ & 45.16 & 1.01 & 6.75 & 13.05 & 0.23 & 0.48 & 16.67 & 1.38 & 2.90 & 0.03 & 11.00 & 6.36 & 6 & 100.0 \\
\hline
\end{tabular}

Normalized bulk sample compositions calculated from weighing (precision $\pm 0.1 \mathrm{mg}$ ) of the different natural samples and synthetic glass $\pm \mathrm{H}_{2} \mathrm{O}$. $\mathrm{Ca}$ (were introduced as $\mathrm{CaF}$ ) was recalculated as $\mathrm{CaO}$; $\mathrm{F}$ was recalculated as $\mathrm{F}_{2} \mathrm{O}_{-1}$ (for compositional balance). 

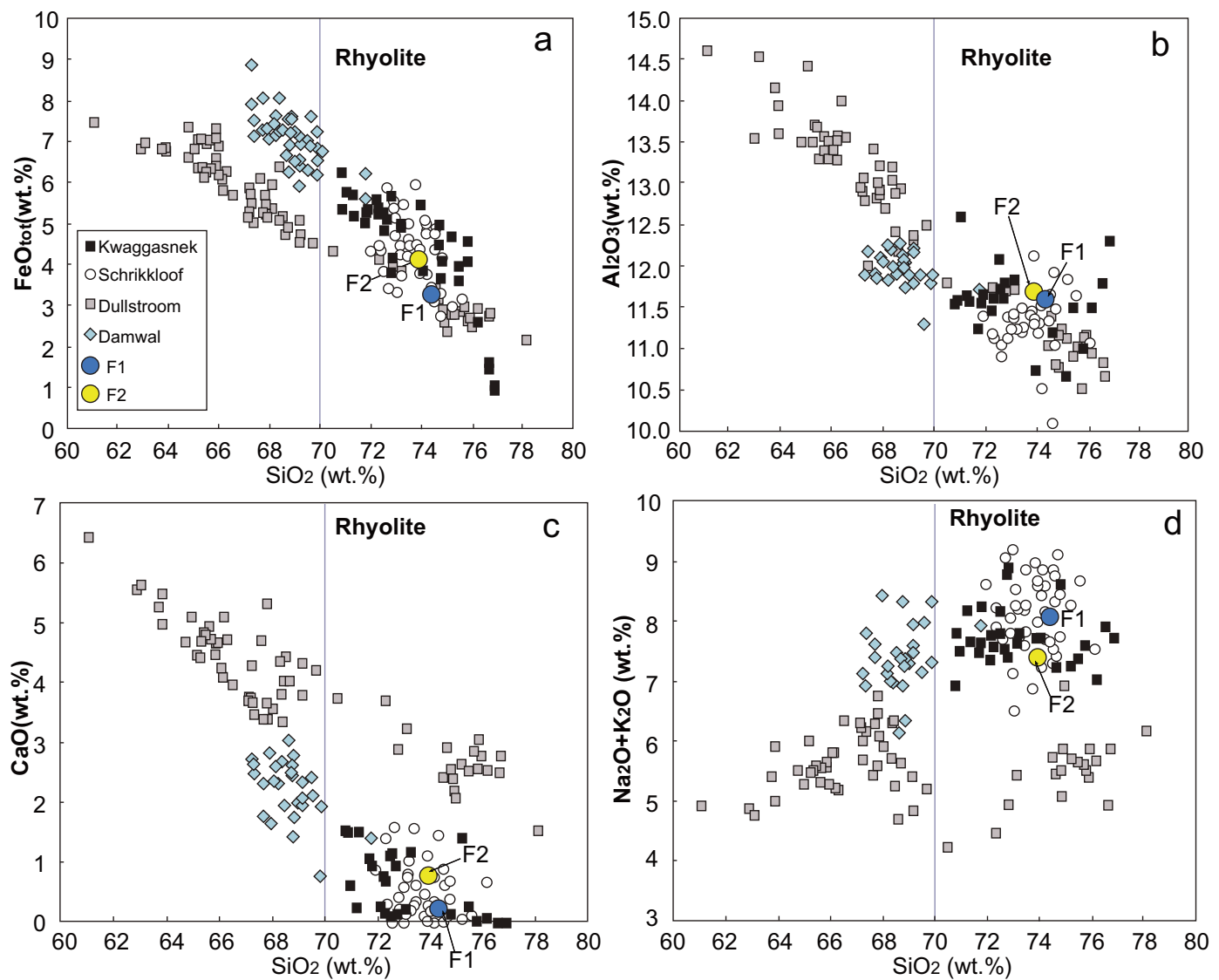

Fig. 3. Harker diagrams illustrating the compositional range of rocks of the Rooiberg Group, including the felsic rocks of Dullstroom, Damwal, Schrikkloof and Kwaggasnek Formations (the data are compiled from Hatton and Schweitzer, 1995; Mathez et al., 2013; Buchanan et al., 2002; Twist and French, 1983). F1 refers to the average composition of Schrikkloof Formation in Hatton and Schweitzer (1995). F2 is the average composition of the rhyolitic rocks from Dullstroom, Schrikkloof and Kwaggasnek Formations.

is in relatively good agreement with the $\mathrm{H}_{2} \mathrm{O}$ concentration measured by FTIR. The water contents of the experimental glasses are presented in Table 4 . The water activity $\left(\mathrm{aH}_{2} \mathrm{O}\right)$ was calculated from the $\mathrm{H}_{2} \mathrm{O}$ content in the melt using the model of Burnham (1994). This model works well up to 2 kbar (e.g. Berndt et al., 2005).

We used several methods to estimate the oxygen fugacity in our experiments. Under $\mathrm{H}_{2} \mathrm{O}$-saturated conditions and intrinsic $f \mathrm{O}_{2}$ conditions of the IHPV, the oxygen fugacity was determined to be $3.3 \mathrm{log}$ units above the oxygen fugacity of the fayalite-magnetite-quartz (FMQ) solid oxygen buffer (hereafter labeled FMQ+3.3). For water-bearing experiments performed at the intrinsic $f \mathrm{O}_{2}$ conditions, which are not saturated in a fluid phase, we used calculated $\mathrm{aH}_{2} \mathrm{O}$ values to estimate the oxygen fugacity of the runs following the method described by Botcharnikov et al. (2005). For the G, H and I series, which were conducted at nominally dry conditions (no fluid added), we assumed an $\mathrm{aH}_{2} \mathrm{O}$ of 0.05 . This is because such experiments are not strictly water-free for two reasons: (1) it is nearly impossible to avoid adsorbed water on the surface of the glass grains, and (2) hydrogen can be present in the pressure medium (gas) and may diffuse through the noble metal capsules. Thus in nominally dry experiments, a fluid phase was not present, but the silicate melts contained small amounts of water mainly present as $\mathrm{OH}$ groups ( 0.3-1.0 wt.\% depending on pressure and extent of crystallization; Almeev et al., 2012).

Other experiments were performed under controlled reduced oxygen fugacity conditions. For these experiments, $\mathrm{H}_{2}$ was added to the Ar pressure medium and the autoclave was equilibrated at a $f \mathrm{O}_{2}$ of $\mathrm{FMQ}+1$ for water-saturated conditions. The dissociation of water is the main reaction controlling redox equilibria inside the capsules. Using the estimated $\mathrm{aH}_{2} \mathrm{O}$ values, the prevailing $f \mathrm{O}_{2}$ was calculated for each water-undersaturated experiment as $\log f \mathrm{O}_{2}^{\text {cap- }}$ sule $=\log f \mathrm{O}_{2}^{\text {apparent }}+2 \log \left(\mathrm{aH}_{2} \mathrm{O}\right)$ (see also Botcharnikov et al., 2005, 2008) where $\log f \mathrm{O}_{2}^{\text {apparent }}$ is the oxygen fugacity that is expected in the system at $\mathrm{aH}_{2} \mathrm{O}=1$.

Results of $\mathrm{aH}_{2} \mathrm{O}$ and $f \mathrm{O}_{2}$ calculations are presented in the Table 3. The error in $f \mathrm{O}_{2}$ mainly depends on the uncertainty of the melt water content and thus $\mathrm{aH}_{2} \mathrm{O}$. In watersaturated samples or in experiments approaching watersaturated conditions, errors are expected to be very low, because a change in melt water content does not result in significant changes of $\mathrm{aH}_{2} \mathrm{O}$ and $f \mathrm{O}_{2}$. In contrast, in highly water-undersaturated samples, a change in water content $(0.5$ wt. $\%)$ implies distinct changes in $\mathrm{aH}_{2} \mathrm{O}$ and $f \mathrm{O}_{2}$. We estimate that the overall error in the calculated $f \mathrm{O}_{2}$ is about $\sim 0.2 \log$ units (Botcharnikov et al., 2005). 
Table 3

Experimental conditions and phase assemblages.

\begin{tabular}{|c|c|c|c|c|c|c|c|c|}
\hline Sample & $\mathrm{T}\left[{ }^{\circ} \mathrm{C}\right]$ & $\mathrm{P}[\mathrm{kbar}]$ & Run duration (h) & $f \mathrm{O}_{2}$ & $f \mathrm{H}_{2}[$ bar $]$ & $\mathrm{aH}_{2} \mathrm{O}$ & Phases & Glass composition (wt.\%) \\
\hline $\mathrm{A} 0 \mathrm{a}$ & 1010 & 2 & 4 & $\mathrm{FMQ}+1.4$ & & 0.11 & Mt (15), Flu (5), Si-glass (76), Fe-glass (4) & $65 \% \mathrm{SiO}_{2}, 11 \% \mathrm{FeO} \& 47 \% \mathrm{SiO}_{2}, 26 \% \mathrm{FeO}$ \\
\hline $\mathrm{A} 0 \mathrm{~b}$ & 1010 & 2.08 & 4 & FMQ-1.0 & 7.64 & 0.13 & Flu (3), Glass (97) & $54 \% \mathrm{SiO}_{2}, 24 \% \mathrm{FeO}$ \\
\hline A0c & 1010 & 1 & 4 & $\mathrm{FMQ}+1.7$ & & 0.16 & Mt (18), Flu (5), Si-glass (66), Fe-glass (10) & $66 \% \mathrm{SiO}_{2}, 12 \% \mathrm{FeO} \& 49 \% \mathrm{SiO}_{2}, 25 \% \mathrm{FeO}$ \\
\hline A5a & 1010 & 2 & 4 & $\mathrm{FMQ}+3.3$ & & 0.98 & Mt (19), Flu (4), Glass (77) & $67 \% \mathrm{SiO}_{2}, 6.8 \% \mathrm{FeO}$ \\
\hline A5b & 1010 & 2.08 & 4 & $\mathrm{FMQ}+1.0$ & 7.64 & 0.96 & Mt (10), Flu (0.3), Glass (90) & $55 \% \mathrm{SiO}_{2}, 17 \% \mathrm{FeO}$ \\
\hline B0a & 1010 & 2.08 & 4 & FMQ-0.4 & 7.64 & 0.21 & Glass (100) & $61 \% \mathrm{SiO}_{2}, 16 \% \mathrm{FeO}$ \\
\hline $\mathrm{B} 0 \mathrm{~b}$ & 1010 & 1 & 4 & $\mathrm{FMQ}+0.8$ & & 0.06 & Mt (9), Flu (6), Si-glass (79), Fe-glass (5) & $67 \% \mathrm{SiO}_{2}, 10 \% \mathrm{FeO} \& 46 \% \mathrm{SiO}_{2}, 22 \% \mathrm{FeO}$ \\
\hline $\mathrm{C} 0 \mathrm{a}$ & 1010 & 1 & 4 & $\mathrm{FMQ}+1.8$ & & 0.18 & Mt (38), Flu (5), Tri (5), Si-glass (32), Fe-glass (22) & $73 \% \mathrm{SiO}_{2}, 9 \% \mathrm{FeO} \& 45 \% \mathrm{SiO}_{2}, 33 \% \mathrm{FeO}$ \\
\hline $\mathrm{D} 2 \mathrm{a}$ & 1010 & 2 & 24 & $\mathrm{FMQ}+3.1$ & & 0.82 & Mt (38), Tri (13), Ap (0), Glass (49) & $69 \% \mathrm{SiO}_{2}, 3.3 \% \mathrm{FeO}$ \\
\hline $\mathrm{D} 4 \mathrm{a}$ & 1010 & 2 & 24 & $\mathrm{FMQ}+3.3$ & & 1 & Mt (33), Glass (67) & $70 \% \mathrm{SiO}_{2}, 3.2 \% \mathrm{FeO}$ \\
\hline D6a & 1010 & 2 & 24 & $\mathrm{FMQ}+3.3$ & & 1 & Mt (34), Glass (66) & $70 \% \mathrm{SiO}_{2}, 3.1 \% \mathrm{FeO}$ \\
\hline $\mathrm{D} 2 \mathrm{~b}$ & 1010 & 1 & 24 & $\mathrm{FMQ}+3.2$ & & 0.78 & Mt (32), Glass (68) & $70 \% \mathrm{SiO}_{2}, 3.5 \% \mathrm{FeO}$ \\
\hline D6b & 1010 & 1 & 24 & $\mathrm{FMQ}+3.3$ & & 1 & Mt (36), Glass (64) & $73 \% \mathrm{SiO}_{2}, 3.4 \% \mathrm{FeO}$ \\
\hline E2a & 1010 & 1 & 24 & $\mathrm{FMQ}+3.2$ & & 0.78 & Mt (32), Glass (68) with nano-emulsion & $68 \% \mathrm{SiO}_{2}, 7.5 \% \mathrm{FeO}$ \\
\hline E4a & 1010 & 1 & 24 & $\mathrm{FMQ}+3.3$ & & 1 & Mt (33), Glass (67) with nano-emulsion & $69 \% \mathrm{SiO}_{2}, 7.3 \% \mathrm{FeO}$ \\
\hline E6a & 1010 & 1 & 24 & $\mathrm{FMQ}+3.3$ & & 1 & Mt (32), Glass (68) with nano-emulsion & $67 \% \mathrm{SiO}_{2}, 8.1 \% \mathrm{FeO}$ \\
\hline $\mathrm{E} 2 \mathrm{~b}$ & 1010 & 1 & 24 & $\mathrm{FMQ}+3.2$ & & 0.85 & Mt (35), Glass (65) & $70 \% \mathrm{SiO}_{2}, 3.6 \% \mathrm{FeO}$ \\
\hline $\mathrm{E} 4 \mathrm{~b}$ & 1010 & 1 & 24 & $\mathrm{FMQ}+3.3$ & & 1 & Mt (34), Glass (66) & $69 \% \mathrm{SiO}_{2}, 4.5 \% \mathrm{FeO}$ \\
\hline E6b & 1010 & 1 & 24 & $\mathrm{FMQ}+3.3$ & & 1 & Mt (36), Glass (64) & $71 \% \mathrm{SiO}_{2}, 3.9 \% \mathrm{FeO}$ \\
\hline G0a & 1010 & 1 & 24 & FMQ-0.6 & 3.48 & 0.05 & Mt (27), Fa (15), Tri (0), Glass (60) & $72 \% \mathrm{SiO}_{2}, 6.7 \% \mathrm{FeO}$ \\
\hline G0b & 1010 & 1 & 24 & FMQ-0.6 & 3.48 & 0.05 & Mt (12), Fa (12), Flu (4), Si-glass (66), Fe-glass (6) & $68 \% \mathrm{SiO}_{2}, 10 \% \mathrm{FeO} \& 41 \% \mathrm{SiO}_{2}, 36 \% \mathrm{FeO}$ \\
\hline G0c & 1010 & 1 & 24 & FMQ- -0.6 & 3.48 & 0.05 & Mt (5), Flu (18), Tri (0), Si-glass (71), Fe-glass (6) & $64 \% \mathrm{SiO}_{2}, 11 \% \mathrm{FeO} \& 41 \% \mathrm{SiO}_{2}, 30 \% \mathrm{FeO}$ \\
\hline H0a & 1010 & 1 & 500 & FMQ-1.4 & 6.01 & 0.05 & Mt (2.5), Glass (97.5) with nano-emulsion & $59 \% \mathrm{SiO}_{2}, 14 \% \mathrm{FeO}$ \\
\hline $\mathrm{HOb}$ & 1010 & 1 & 500 & FMQ-1.4 & 6.01 & 0.05 & Mt (3.5), Flu (2.5), Glass (94) with nano-emulsion & $59 \% \mathrm{SiO}_{2}, 13 \% \mathrm{FeO}$ \\
\hline $\mathrm{H} 0 \mathrm{c}$ & 1010 & 1 & 500 & FMQ-1.4 & 6.01 & 0.05 & Mt (2), Flu (16), Si-glass (60), Fe-glass (22) & $61 \% \mathrm{SiO}_{2}, 12 \% \mathrm{FeO} \& 49 \% \mathrm{SiO}_{2}, 20 \% \mathrm{FeO}$ \\
\hline $\mathrm{I} 0 \mathrm{a}$ & 1010 & 1 & 168 & $\mathrm{FMQ}+1.0$ & 2.30 & 0.05 & Mt (18), Tri (10), Ol (0), Glass (72) with nano-emulsion & $75 \% \mathrm{SiO}_{2}, 2.8 \% \mathrm{FeO}$ \\
\hline $\mathrm{I} 0 \mathrm{~b}$ & 1010 & 1 & 168 & $\mathrm{FMQ}+1.0$ & 2.30 & 0.05 & Mt (13), Flu (3), Tri (0), Si-glass (81), Fe-glass (4) & $67 \% \mathrm{SiO}_{2}, 6.9 \% \mathrm{FeO} \& 51 \% \mathrm{SiO}_{2}, 15 \% \mathrm{FeO}$ \\
\hline I0c & 1010 & 1 & 168 & $\mathrm{FMQ}+1.0$ & 2.30 & 0.05 & Mt (7), Flu (18), Tri (0), Si-glass (60), Fe-glass (16) & $68 \% \mathrm{SiO}_{2}, 7.3 \% \mathrm{FeO} \& 46 \% \mathrm{SiO}_{2}, 22 \% \mathrm{FeO}$ \\
\hline J6a & 1010 & 1 & 120 & FMQ+1.0 & 4.30 & 1 & Mt (10), Flu (0.5), Fa (0.5), Glass (89) & $63 \% \mathrm{SiO}_{2}, 9.4 \% \mathrm{FeO}$ \\
\hline $\mathrm{J} 6 \mathrm{~b}$ & 1010 & 1 & 120 & $\mathrm{FMQ}+1.0$ & 4.30 & 1 & Mt (10), Flu (5), Fa (2), Glass (83) & $63 \% \mathrm{SiO}_{2}, 9.8 \% \mathrm{FeO}$ \\
\hline $\mathrm{J} 6 \mathrm{c}$ & 1010 & 1 & 120 & $\mathrm{FMQ}+1.0$ & 4.30 & 1 & Mt (10), Flu (18), Fa (2), Glass (70) & $63 \% \mathrm{SiO}_{2}, 6.6 \% \mathrm{FeO}$ \\
\hline
\end{tabular}

Phase proportions were calculated by mass balance as well as optical estimations. "0" means trace amount. Total iron as FeO. Details on the calculation of oxygen fugacity and water activity can be found in the text. For G, H and I series, we assumed a water activity of 0.05 . When the forsterite (Fo) content is $>10 \%$, it is defined as olivine. Abbreviations: Ap - apatite, Mt - magnetite, Fa fayalite, Flu - fluorite, Tri - tridymite, $\mathrm{Ol}$ - olivine. 

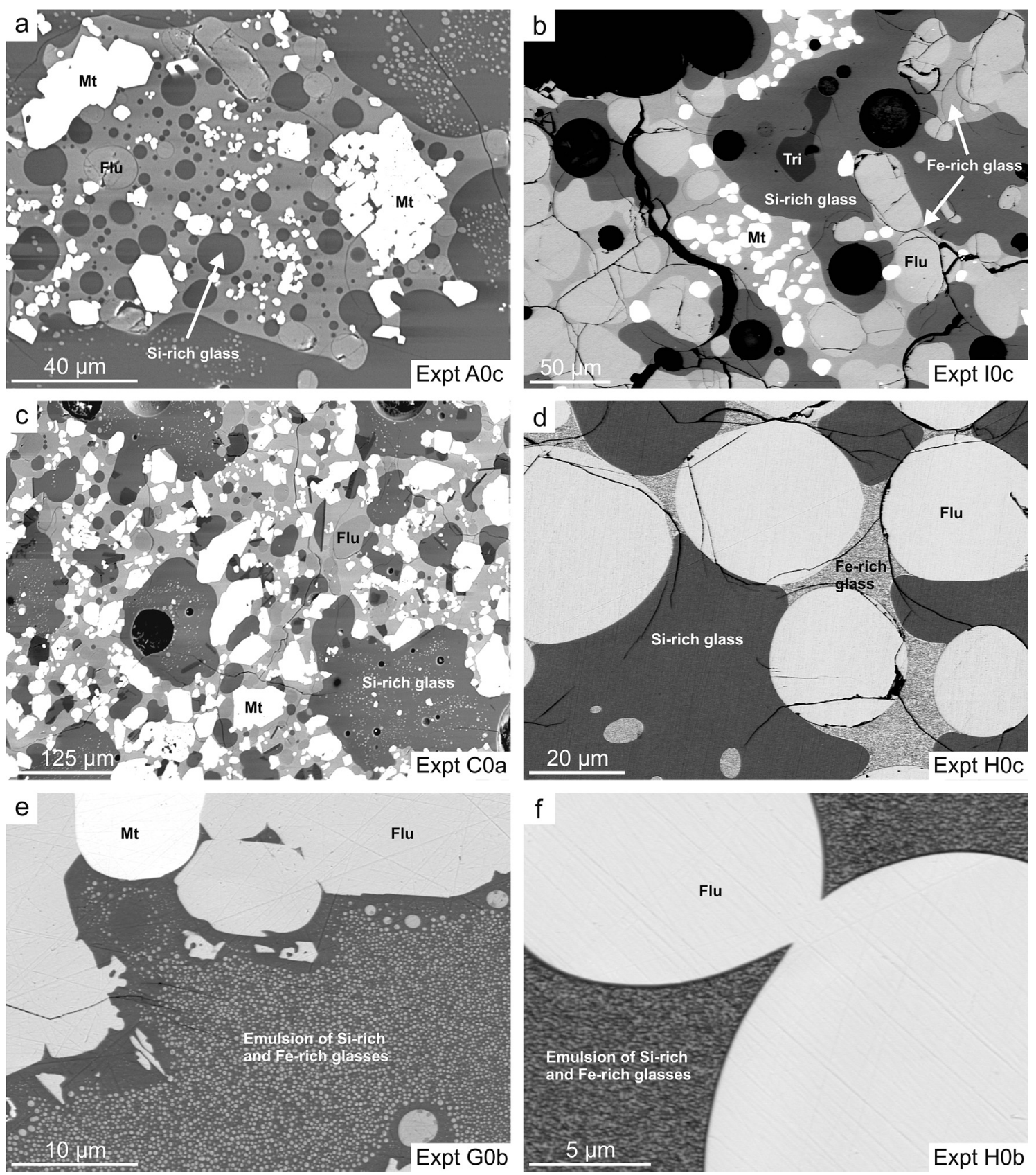

Fig. 4. Back-scattered electron (BSE; a and c) and QEMSCAN (b, d-f) images of experiments showing silicate liquid immiscibility. (a) Sample A0c shows a typical irregularly-shaped (coalesced) patch of Fe-rich glass within Si-rich glass as well as numerous small globules of Fe-rich and Si-rich glass. Large, euhedral grains of magnetite and spherical fluorite also occur. (b) Sample I0c: Magnetite and/or spherical fluorite are preferentially enclosed by the immiscible Fe-rich liquid. (c) Sample C0a: large amounts of Fe- and Si-rich glasses as well as smaller Fe-rich glass globules. Fluorite and magnetite, euhedral grains of tridymite (dark grey) represent the solid phases. (d) Sample H0c: irregularly-shaped (coalesced) patch of Fe-rich glass (or emulsion) within Si-rich glass. Large, euhedral grains of spherical fluorite occur. (e) Sample G0b and (f) Sample H0b: Emulsion of Si-rich and Fe-rich glasses occurring in the Si-rich homogenous glass. Abbreviations: Mt $=$ magnetite, Flu $=$ fluorite, Tri $=$ tridymite.

\section{EXPERIMENTAL RESULTS}

\subsection{Phase equilibria and immiscibility textures}

Table 3 summarizes the conditions and phase assemblages of experimental runs. Figs. 4 and 5 show representative BSE images of the experimental run products acquired on the electron microprobe and QEMSCAN FEI Quanta $650 \mathrm{~F}$ at RWTH Aachen. Crystalline phases observed in experiments are fluorite, magnetite, fayalite (or olivine when the forsterite content is higher than $10 \%$ ), a silica phase (tridymite), and occasionally trace amounts of apatite. Experiments can be classified into three groups: experiments showing distinct liquid immiscibility between 

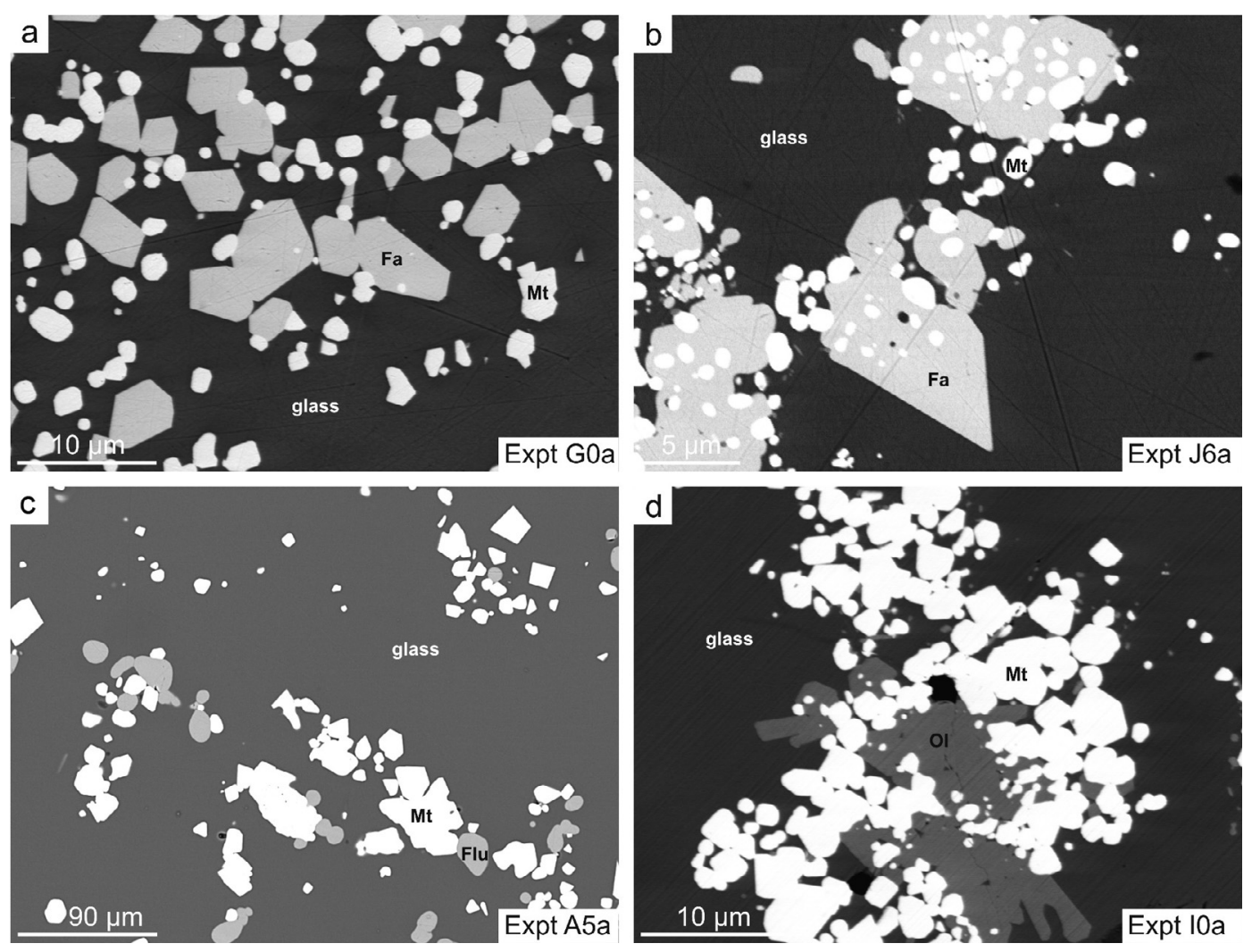

Fig. 5. Representative BSE (c) and QEMSCAN (a, b and d) images of experiments without liquid immiscibility. (a) Sample G0a: Si-rich glass hosting rounded shaped magnetite and fayalite. Note that some of the fayalite crystals contain rounded shaped magnetite. Sample A5a: a homogeneous Fe-rich glass hosts grains of magnetite and fluorite. (b) Sample J6a: a homogeneous Si-rich glass hosting grains of magnetite and fayalite. (c) Sample A5a: magnetite and fluorite in a groundmass of homogeneous Si-rich glass. (d) Sample I0a: Si-rich glass hosting rounded shaped magnetite and olivine.

two silicate liquids, experiments containing a nanoemulsion of immiscible liquids and experiments with a single homogeneous silicate glass.

In the first type of experimental products, pairs of distinct immiscible liquids occur in nine samples, A0a, A0c, B0b, C0a, G0b, G0c, H0c, I0b and I0c. Sharp two-liquid interfaces are usually observed (Fig. 4a-d). Immiscible liquids form small globules, or branching, skeletal structures within each other that may coalesce and form larger aggregates. The Fe-rich immiscible liquid in some of these samples also host nano-scale emulsion of Si-rich liquid (Fig. 4d). No compositional difference between small and large droplets is observed, supporting complete equilibration of the two liquids. The Fe-rich liquid has very small wetting angles with magnetite and fluorite. Magnetite and fluorite crystals preferentially occur in the Fe-rich immiscible melts (Fig. 4b) but they are also found in the Si-rich glasses. Tridymite crystals are also hosted by both immiscible melts. Fluorite crystals are present in all the samples showing distinct liquid immiscibility.

In the second type of experimental products, the immiscible conjugates form 'emulsion' structures on the scale of $<100-500 \mathrm{~nm}$ (Fig. 4e-f). This feature is interpreted as a result of a low efficiency of melt-melt separation, possibly caused by close proximity to the apex of the miscibility gap in the multicomponent composition space, just below the binodal (Charlier and Grove, 2012). In some of these experiments, the globule size is too small to measure the composition of the paired immiscible liquids by electron microprobe.

In the third type of experimental products, the samples do not show liquid immiscibility. They are characterized by the ubiquitous presence of magnetite + fluorite \pm tridymite \pm fayalite (or olivine) \pm apatite (Fig. 5). Both euhedral and rounded subhedral magnetite and fluorite crystals, and tiny apatites are observed. In sample G0a and I0a, fayalite and olivine occur as euhedral crystals co-existing with rounded subhedral magnetite (Figs. 5a,b and d). The glass compositions are presented below, but it is worth noting that samples with rhyolitic glass have considerable amounts of magnetite (18-38 wt.\%; Table 3), whereas those with a relatively Fe-rich (intermediate) melt have less than $30 \mathrm{wt}$. $\%$ crystals, including magnetite and fluorite.

\subsection{Liquid compositions}

The compositions of experimental liquids are shown in Fig. 6 where they are compared to immiscible melts in experimental ferrobasaltic systems (Charlier and Grove, 2012). In the first type of experimental products where we observe distinct immiscible pairs, the Si-rich liquids (62.75-73.00 wt.\% $\quad \mathrm{SiO}_{2}, \quad 6.90-12.48$ wt. $\% \quad \mathrm{FeO}_{\text {tot }}$ and 

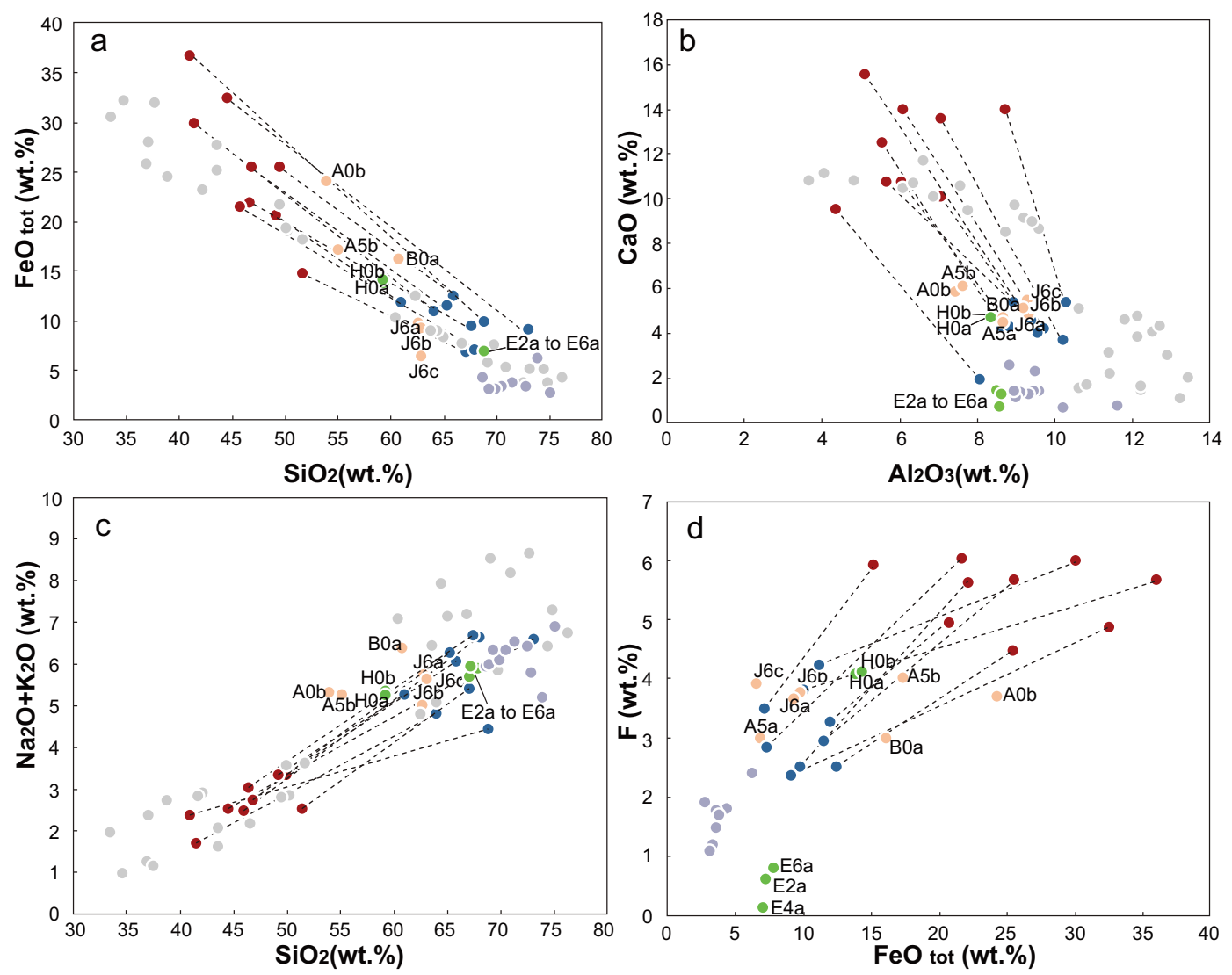

$\begin{array}{ll}\text { - Fe-rich immiscible liquid } & \text { Intermediate homogeneous liquid } \\ \text { - Si-rich immiscible liquid } & \text { - Rhyolitic homogeneous liquid } \\ \text { - liquid with nano-emulsion } & \text { Immiscible liquids from } \\ & \text { Charlier and Grove, } 2012\end{array}$

Fig. 6. Selected major element oxides in experimental glasses. (a) $\mathrm{FeO}_{\text {tot }}$ versus $\mathrm{SiO}_{2}$; (b) $\mathrm{CaO}$ versus $\mathrm{Al}_{2} \mathrm{O}_{3}$; (c) total alkalis versus $\mathrm{SiO}$; (d) $\mathrm{F}$ versus $\mathrm{FeO}_{\text {tot }}$. The composition of the immiscible pairs produced at one atmosphere at FMQ buffer under anhydrous conditions from Charlier and Grove (2012) are plotted for comparison.

2.35-4.24 wt. $\%$ F) are enriched in $\mathrm{Na}_{2} \mathrm{O}, \mathrm{K}_{2} \mathrm{O}$ and $\mathrm{Al}_{2} \mathrm{O}_{3}$ (Table 4). The Fe-rich immiscible melts (40.95-51.40 wt.\% $\mathrm{SiO}_{2}, 14.81-36.09$ wt. $\% \mathrm{FeO}_{\text {tot }}$ and 4.50-6.45 wt.\% F), are enriched in $\mathrm{MgO}, \mathrm{CaO}$ and $\mathrm{TiO}_{2}$. The partitioning coefficient of $\mathrm{F}$ between the $\mathrm{Fe}$ - and Si-rich immiscible conjugates is between 1.42 and 2.23 (Fig. 6d), similar to the values observed in the simplified systems $\mathrm{Fe}_{2} \mathrm{SiO}_{4}-$ $\mathrm{Fe}_{3} \mathrm{O}_{4}-\mathrm{KAlSi}_{2} \mathrm{O}_{6}-\mathrm{SiO}_{2} \pm \mathrm{F} \pm$ plagioclase (Lester et al., 2013). Compared to the immiscible pairs produced in dry conditions at 1 bar (Charlier and Grove, 2012), our samples show lower $\mathrm{SiO}_{2}$ contents in the Fe-rich melt and lower $\mathrm{Al}_{2} \mathrm{O}_{3}$ in the Si-rich melt (Fig. 6a-c). The distinct Si-rich immiscible melts produced in our study show similar $\mathrm{SiO}_{2}, \mathrm{CaO}$ and alkali contents compared to the dacites and low-silica rhyolites of the Dullstroom and Damwal Formations. However, they are more primitive than the rhyolite of the Schrikkloof Formation which hosts the Vergenoeg pipe (Fig. 7). The immiscible Si-rich liquids have higher $\mathrm{FeO}$ contents and lower $\mathrm{Al}_{2} \mathrm{O}_{3}$ contents than any rhyolite from the Rooiberg Group.
The second type of experiments with nano-scale emulsion of immiscible melts is represented by samples H0a, $\mathrm{H} 0 \mathrm{~b}, \mathrm{E} 2 \mathrm{a}, \mathrm{E} 4 \mathrm{a}$ and E6a. In these, the glass compositions that we measured are thought to represent the bulk composition of the nano-emulsions (Table 4).

In the last type of experiments that do not show liquid immiscibility, we can also discriminate two groups. The first one (A5a, D series, E2b, E4b, E6b, and G0a and I0a) has rhyolitic liquids $\left(67-74\right.$ wt. $\% \mathrm{SiO}_{2} ; 2.8-6.8$ wt. $\left.\% \mathrm{FeO}_{\text {tot }}\right)$ with relatively low fluorine (1.14-3.01 wt.\% F). High $\mathrm{SiO}_{2}$ contents are due to the significant crystallization of magnetite and fayalite (Fig. 6). The second one (A0b, A5b, $\mathrm{B} 0 \mathrm{a}$ and $\mathrm{J}$ series) has intermediate melt compositions (54 63 wt. $\% \mathrm{SiO}_{2} ; 6.6-24$ wt. $\left.\% \mathrm{FeO}_{\text {tot }}\right)$, and contain moderate amounts of fluorine (2.99-4.10 wt.\% F; Fig. 6).

\subsection{Olivine (Fayalite) and magnetite compositions}

The compositions of olivine and magnetite in the experimental products are presented in the Supplementary data. 

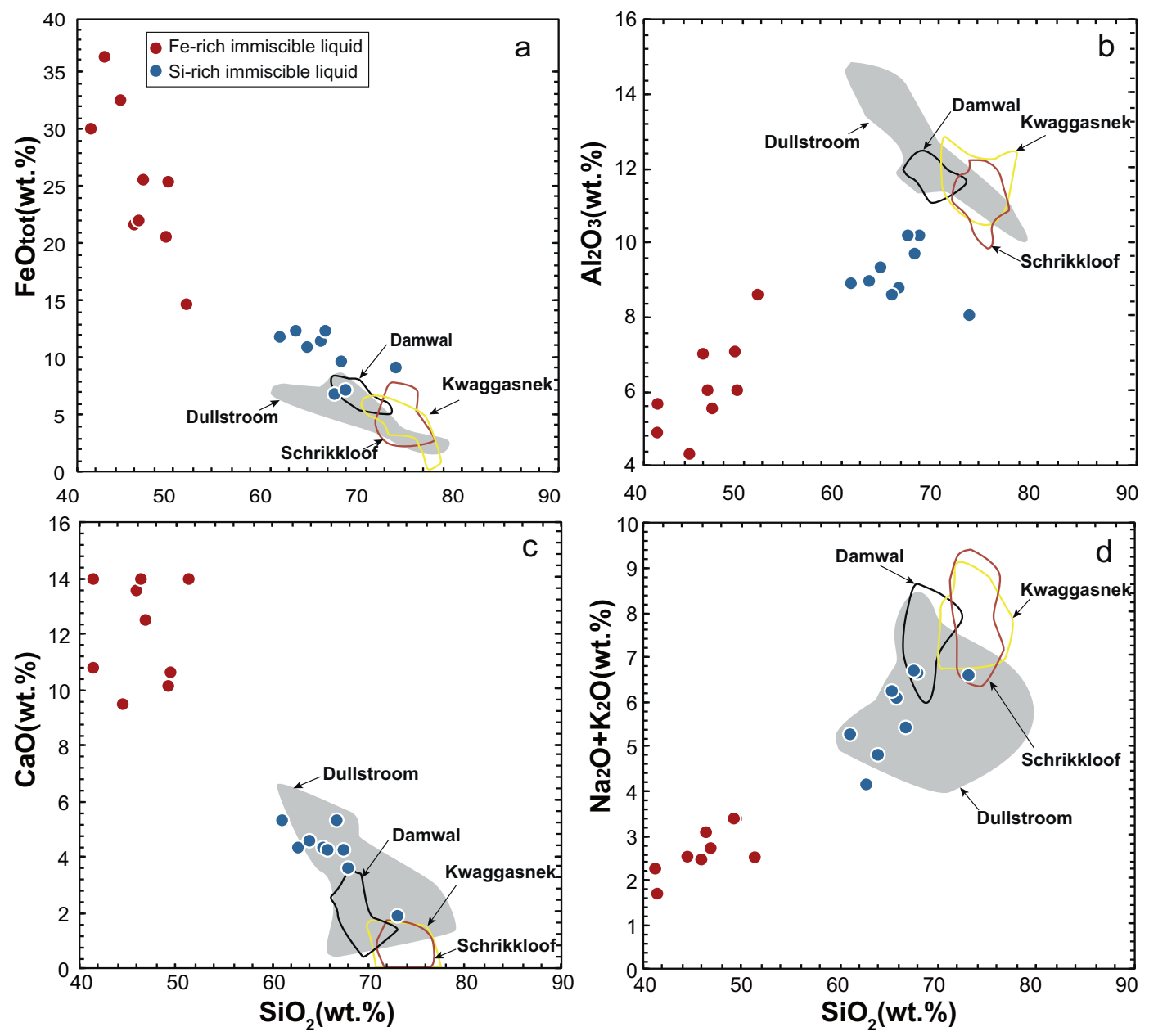

Fig. 7. Selected major element composition of experimental immiscible pair of glasses. The felsic volcanic rocks of the Rooiberg Group including Dullstroom, Damwal, Schrikkloof and Kwaggasnek Formations upwards are also shown for comparison.

Olivine crystals in three samples (G0a, G0b and I0a) have been analyzed. The composition of the olivine in samples G0a and $\mathrm{G} 0 \mathrm{~b}\left(\mathrm{SiO}_{2}:\right.$ 29.51-30.42 wt.\%; $\mathrm{FeO}_{\text {tot }}$ : 62.6164.84 wt.\%; Fo number: 7.4-8.2) is classified as fayalite and is similar to the natural samples (Borrok et al., 1998). Whereas sample I0a has olivine with a fayalite content of only $38 \%$. The ratio of $\mathrm{FeO}$ to $\mathrm{MgO}$ in the olivine crystals as a function of the ratio of $\mathrm{FeO}$ to $\mathrm{MgO}$ in the liquid phase is shown for our experimental runs in Fig. 8a. We can see that the $\mathrm{Kd}_{\text {fayalite-melt }}^{\mathrm{Fe} \text {-Mg }}$ for the limited number of fayalite crystals plots above the line of $\mathrm{Kd}=0.3$, and that the $\mathrm{Kd}$ values for the immiscible Fe-rich liquids are comparable to those for the Si-rich conjugates. The $\mathrm{Kd}$ value for olivine in sample I0a is close to 0.3 . These observations could be explained by the F-rich characteristics of our experiments, as illustrated in Fig. $8 \mathrm{~b}$ in which the $\mathrm{Kd}$ values are plotted as a function of $\mathrm{F}$ (wt.\%). With increasing fluorine in the liquids, the $\mathrm{Kd}$ value dramatically increases for fayalite, suggesting that fluorine in the liquids complexes primarily with $\mathrm{MgO}$, thus decreasing $\mathrm{MgO}$ activity, and shifting the $\mathrm{Fe} / \mathrm{Mg}$ ratio of crystallizing minerals to higher values. We note that our calculated $\mathrm{Kd}$ values $(0.49$ for $\mathrm{G} 0 \mathrm{a}, 0.58$ and 0.55 for $\mathrm{Fe}$ and Si-rich liquids of $\mathrm{G} 0 \mathrm{~b}$, respectively) are consistent with those observed in experiments of Frich Martian basalts (Filiberto et al., 2012).

Magnetite compositions range between $\mathrm{Mt}_{0.98} \mathrm{Usp}_{0.02}$ and $\mathrm{Mt}_{0.41} \mathrm{Usp}_{0.59} \quad(\mathrm{Mt}=$ magnetite; $\mathrm{USp}=$ ulvöspinel $)$. The variation of calculated ulvöspinel end-member contents in magnetite is plotted against the $\mathrm{TiO}_{2}$ content in equilibrium melts in Fig. 8c. The negative correlation between $f \mathrm{O}_{2}$ and the calculated ulvöspinel content in magnetite is consistent with $f \mathrm{O}_{2}$ being the key factor in controlling the composition of magnetite (Fig. 8d; Buddington and Lindsley, 1964; Toplis and Carroll, 1995).

\section{DISCUSSION}

\subsection{The onset of silicate liquid immiscibility}

\subsubsection{The role of fluorine}

In dry multicomponent magmatic systems, an extreme iron enrichment $(>18-19$ wt.\% FeO) has usually been considered as necessary for the onset of unmixing (Dixon and Rutherford, 1979; Philpotts and Doyle, 1983). Although 

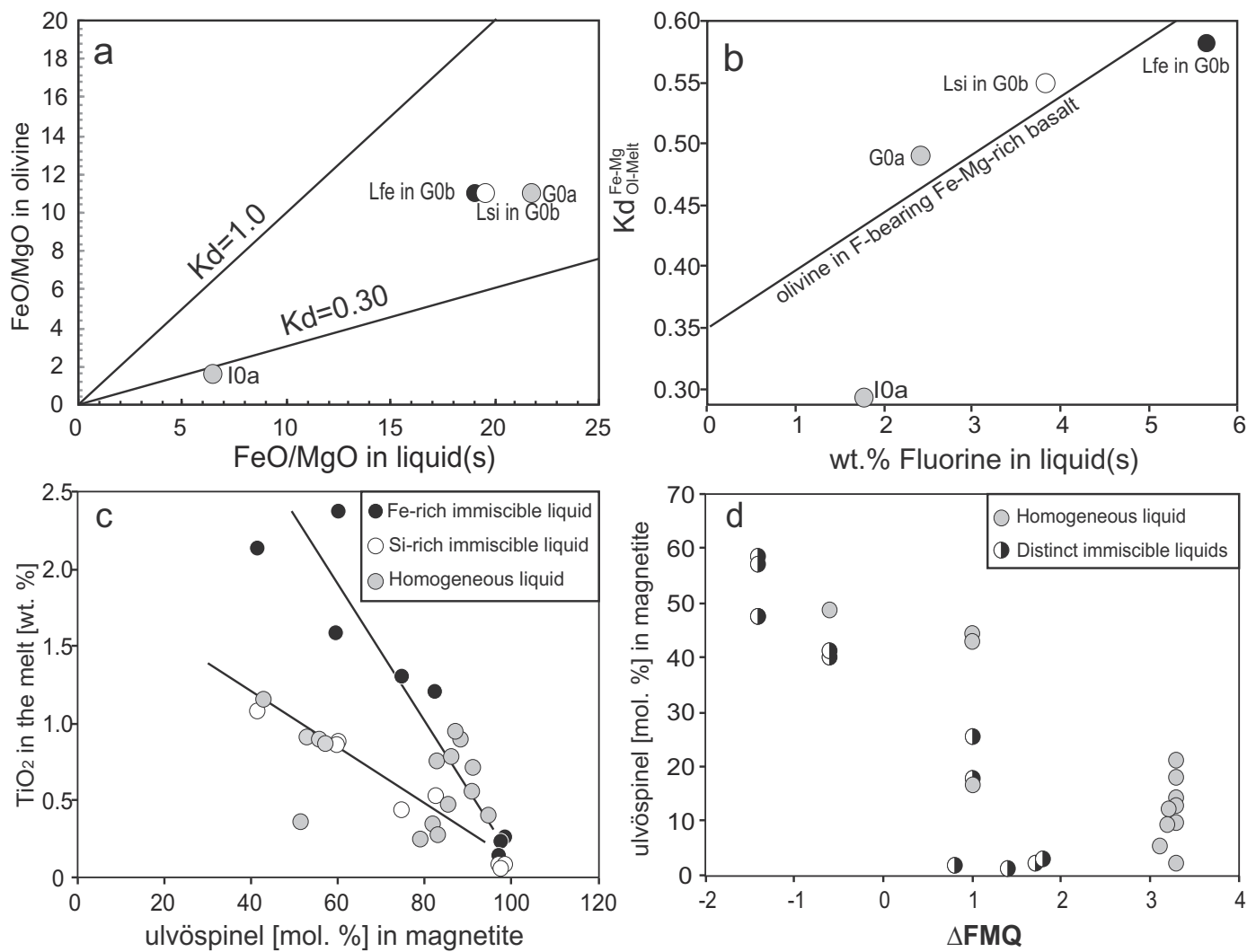

Fig. 8. (a) $\mathrm{FeO} / \mathrm{MgO}$ ratio (mol.\%) olivine vs $\mathrm{FeO} / \mathrm{MgO}$ ratio in melt in the $\mathrm{G} 0 \mathrm{a}, \mathrm{G} 0 \mathrm{~b}$ and $\mathrm{I} 0$ a runs; (b) $\mathrm{Kd}^{\mathrm{Fe}-\mathrm{Mg}}$ as a function of $\mathrm{F}$ (wt.\%) for fayalite-bearing experimental charges. The black line is from the linear regression through the data for olivine-bearing $\mathrm{Fe}-\mathrm{Mg}$ rich basalt (Filiberto et al., 2012); (c) Variation of $\mathrm{TiO}_{2}$ content in the melt and calculated ulvöspinel end-member contents in magnetite from experimental charges. Black lines represent linear regressions through the data $\left(r^{2}=0.88\right)$ for the immiscible Fe-rich liquids, and $\left(r^{2}=0.96\right)$ for the Si-rich conjugates. (d) Calculated ulvöspinel end-member contents in magnetite vs $\triangle \mathrm{FMQ}$. FMQ = fayalite-magnetite-quartz solid buffer. $\mathrm{Lsi}=$ Si-rich liquid, $\mathrm{Lfe}=$ Fe-rich liquid.

the $\mathrm{FeO}$ activity probably needs to be high, the experiments of Charlier and Grove (2012) demonstrated that extreme iron enrichment is not necessary to reach the two-liquid field. Liquid immiscibility could also develop during the silica-enrichment that follows $\mathrm{Fe}-\mathrm{Ti}$ oxide saturation in the melt. This is consistent with our experiments showing that many runs with liquid immiscibility also contain abundant magnetite.

In the case of Vergenoeg-related compositions, distinct liquid immiscibility occur only in samples in which fluorite is observed as a stable phase, which indicates that fluorine is one of the key factors that could facilitate immiscibility. This is illustrated by the plot of the bulk fluorine contents in experiments versus the fluorine contents of experimental liquids (Fig. 9a), which shows that only fluorine-rich experiments $(>3.4$ wt.\% bulk F) developed distinct immiscibility. We interpret this as resulting from fluorine complexing with $\mathrm{MgO}$ (Filiberto et al., 2012) in the melt, therefore increasing the activity of $\mathrm{FeO}$, which is a favorable condition for the development of liquid immiscibility (Philpotts and Doyle, 1983). Potentially fluorine may also change the shape of the binodal by the reaction of fluorine with $\mathrm{Si}-\mathrm{O}-\mathrm{Si}$ bonds to form Si-F and Al-F bonds (Manning, 1981), which leads to a depolymerization of the melt structure (Dingwell, 1985;
Giordano et al., 2004) and therefore a decrease of the liquidus temperature.

Although fluorite-saturation seems to promote the development of silicate liquid immiscibility, a high fluorine content by itself is insufficient to trigger the unmixing. As shown in Fig. 9a, some samples with $>2 \mathrm{wt} \%$ fluorine (e.g., J series) did not develop immiscibility. In contrast, Lester et al. (2013) report experiments with lower fluorine contents $(<2$ wt. $\%)$ which also have immiscible Fe-rich and Si-rich liquids.

\subsubsection{The role of oxygen fugacity}

Oxygen fugacity $\left(f \mathrm{O}_{2}\right)$ has a significant influence on the development of immiscibility (Naslund, 1983). In our experiments, immiscible liquids occur in experiments performed at relatively reducing conditions from FMQ-1.4 to FMQ+1.8 (Fig. 9b). Naslund (1983) has shown that a high $\mathrm{Fe}_{2} \mathrm{O}_{3} / \mathrm{FeO}$ ratio (high $f \mathrm{O}_{2}$ ) widens the two-liquid field under super-liquidus conditions and increases the upper temperature limit of immiscibility in the system $\mathrm{KAlSi}_{3} \mathrm{O}_{8}$ $\mathrm{FeO}-\mathrm{Fe}_{2} \mathrm{O}_{3}-\mathrm{SiO}_{2}$. This would, in theory, enhance the development of immiscibility. However, most of our experiments run under highly oxidizing environments (>FMQ +3 ) crystallized considerable amounts of magnetite, which 

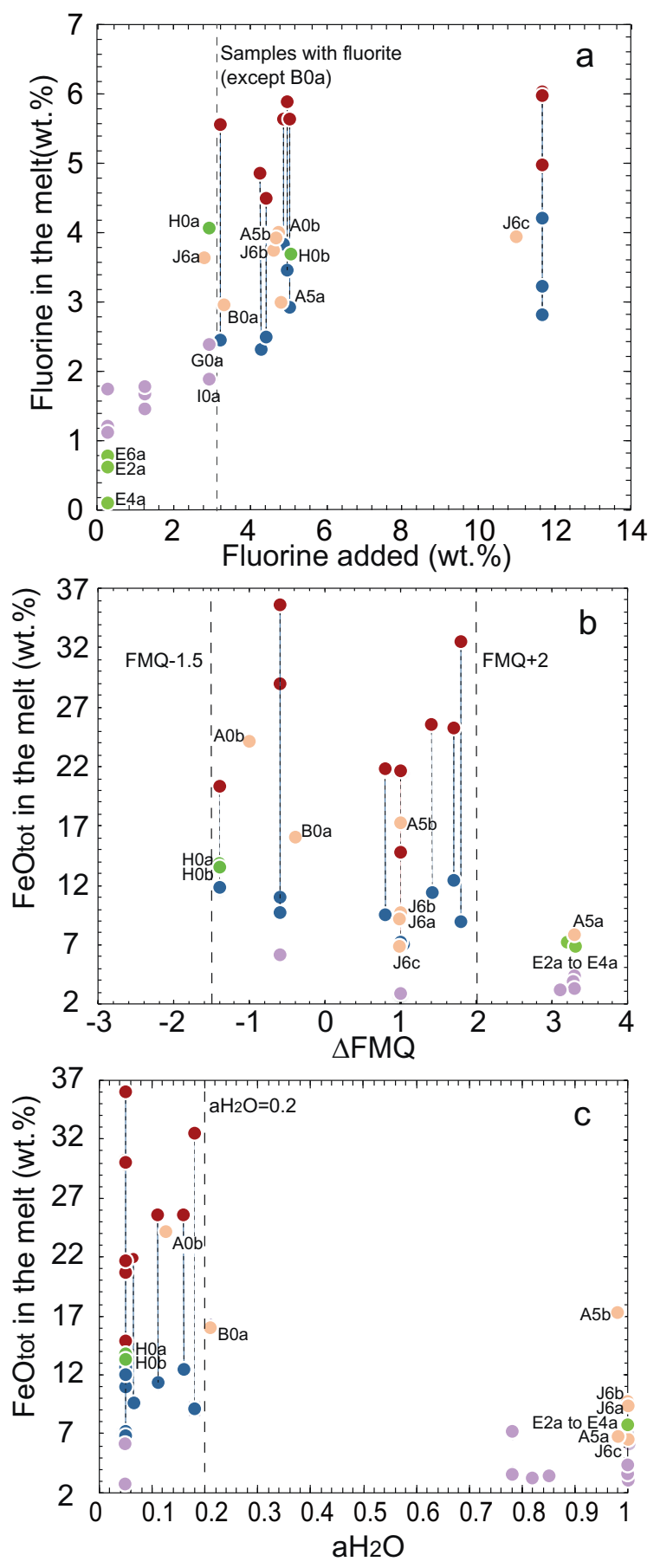

Fig. 9. (a) Bulk $\mathrm{F}$ in experimental charges vs $\mathrm{F}$ in the experimental glasses. (b) $\mathrm{FeO}_{\text {tot }}$ in the melt vs $\triangle \mathrm{FMQ}$. (c) $\mathrm{FeO}_{\text {tot }}$ content in experimental glasses vs activity of water in the experimental runs. The symbols are same as in Fig. 6.

led to a strong iron depletion in the residual melt (Fig. 9b) and hampered the development of immiscibility. We conclude that the enlargement of the immiscibility field caused by high $f \mathrm{O}_{2}$, as observed by Naslund (1983) in a superliquidus systems, is strongly counteracted by the stabilization of magnetite and resultant iron depletion that occurs in natural systems. It is worth noting that some F-rich sam- ples, run under relatively reducing conditions, do not show immiscible textures. This implies that immiscibility is not only controlled by the bulk $\mathrm{F}$ content and $\mathrm{fO}_{2}$ but that other compositional features must play a dominant role in liquid unmixing.

\subsubsection{The effect of water}

Fig. 9c shows that distinct silicate liquid immiscibility only developed in the samples with low $\mathrm{H}_{2} \mathrm{O}$ contents, i.e. $\mathrm{aH}_{2} \mathrm{O}<0.2$, suggesting that water suppresses the development of silicate liquid immiscibility. This has been confirmed by the comparison between I and $\mathbf{J}$ series, which have the same bulk composition (Table 2) and which were conducted at the same $f \mathrm{O}_{2}(\mathrm{FMQ}+1)$. The water-saturated $\mathrm{J} 6 \mathrm{~b}$ and J6c samples show no liquid immiscibility whereas their counterparts, I0b and I0c, contain two liquids. However, the role of water in the development of immiscibility is relatively subtle. We believe that $\mathrm{H}_{2} \mathrm{O}$ may shift the critical temperature of the binodal below the liquid line of descent. Lester et al. (2013) have shown that $\mathrm{H}_{2} \mathrm{O}$ enlarges the solvus in silicate melts and therefore decreases the temperature of the solvus apex. The effect of water on the liquidus temperature of the magma may be important leading to a liquid line of descent that never hits the binodal surface.

\subsection{Model for the origin of the Vergenoeg deposit}

Based on the experimental results and discussions presented above, we observe that (1) moderate iron content in the starting composition; (2) high fluorine content, i.e. saturation of fluorite in the liquid; (3) moderate temperatures $\left(1010^{\circ} \mathrm{C}\right)$ and $f \mathrm{O}_{2}(\mathrm{FMQ}-1.4$ to $\mathrm{FMQ}+1.8)$ and (4) low water content $\left(\mathrm{aH}_{2} \mathrm{O}<0.2\right)$, are the right conditions for the development of liquid immiscibility.

Based on our experimental results, we propose a model for the petrogenesis of the Vergenoeg deposit. Essentially, the model constitutes a revised and extended version of the model proposed by Crocker (1985). In the case of Vergenoeg, it is envisaged that immiscibility occurred simply as a result of temperature decrease, compositional evolution and enrichment of $F$ in the residual melt. This process possibly resulted in the formation of a stratified magma chamber with the denser Fe-rich melt forming the lower zone of the magma chamber, whereas the overlying Si-rich melt was located in the upper parts (Fig. 10).

Compared to the average composition of the ores (M0), the iron-rich immiscible liquid obtained experimentally contains higher $\mathrm{SiO}_{2}$ and lower $\mathrm{FeO}_{\text {tot }}$ (Tables 1 and 4). This indicates that the bulk composition of the ore (pipe) may not simply represent a crystallized immiscible Fe-rich melt. As observed in our experiments showing liquid immiscibility, fluorite, together with magnetite and fayalite, are the stable liquidus phases. Thus, we suggest that the pipe may be a cumulate (or crystal mush) coexisting with small proportions of the unmixed Fe-rich melt. The mush, consisting of magnetite, fayalite and interstitial Fe-rich melt, has significantly higher bulk $\mathrm{Fe}$ and lower $\mathrm{Al}_{2} \mathrm{O}_{3}$ contents compared to the immiscible Fe-rich melt, within the range of the Vergenoeg pipe bulk composition. If the magnetite crystals within this magma were not distributed uniformly, 


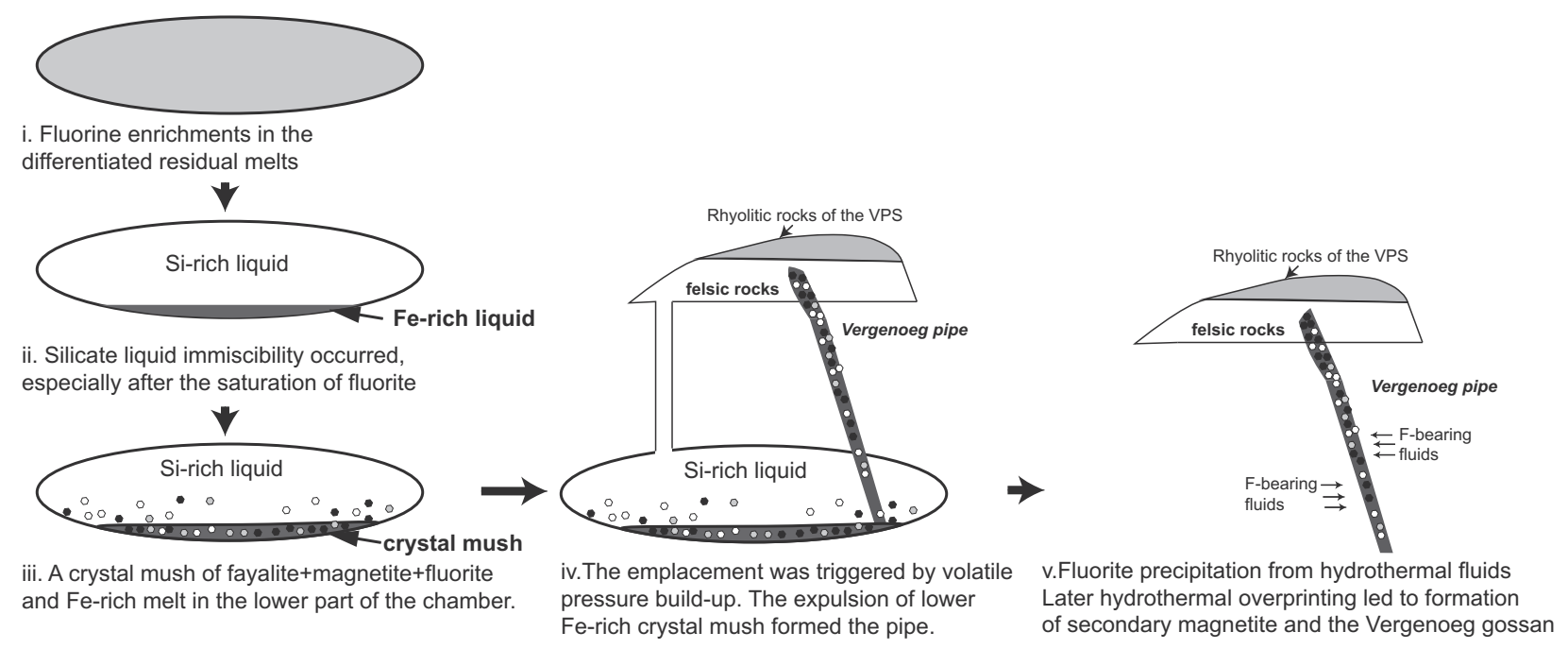

Fig. 10. A schematic model for the formation of the Vergenoeg Fe-F deposit. (i) Fluorine becomes enriched in the magma; (ii) development of silicate liquid immiscibility in the magma chamber; (iii) formation of crystal mush, crystallization of fayalite + magnetite which are concentrated in the iron-rich melt; (iv) eruption of Si-rich melt and emplacement of Fe-rich crystal much leading to the formation of Vergenoeg pipe; (v) secondary fluorine enrichment in the pipe probably as a result of post-magmatic hydrothermal fluids. Note that the proportion of Fe-rich and Si-rich liquid may not reflect the real proportion.

this might also explain the formation of different lithological units within the pipe. In our experiments, fayalite was only produced under $f \mathrm{O}_{2}$ close to $\mathrm{FMQ}$, suggesting that such conditions prevailed during the crystallization of the Vergenoeg intrusion.

Volatile pressure build-up resulted in the emplacement of the crystal mush and formation of the Vergenoeg pipe (Crocker, 1985). This model is in contrast to Borrok et al. (1998), who suggested that the Ti-poor magnetite observed at Vergenoeg mainly formed as an alteration product of primary fayalite. In our experiments, fayalite and magnetite crystals coexist, implying that most fayalite and magnetite can be considered as the primary magmatic phases. Moreover, such Ti-poor magmatic magnetites have also been documented recently in natural samples related to Kiruna ores (Dare et al., 2014b; Knipping et al., 2015a).

As stated above, if the pipe was formed by solidification of an Fe-rich crystal mush, the bulk fluorine contents of the pipe should not exceed that of the Fe-rich melt, unless considerable amounts of fluorite-bearing cumulates formed and expelled a F-poor residual liquid. However, the estimated fluorine content of the pipe, $\sim 12 \mathrm{wt} . \% \mathrm{~F}$ (Table 1 ), is about two times greater than that in the Fe-rich melt at fluorite saturation $(\sim 6 \mathrm{wt} . \% \mathrm{~F}$; Table 4$)$. This requires at least half of the immiscible Fe-rich melt volume to be expelled after fayalite + magnetite + fluorite crystallized. We therefore believe that the huge amount of fluorine $(\sim 12 \mathrm{wt} . \% \mathrm{~F}$ in the ores with a magnetite/fluorite ratio of $\sim 5: 1$ ) observed in the deposit cannot originate solely from the crystallization of fluorite from the Fe-rich silicate melt. This is supported by fluorite crystals in the pipe which have three types of inclusions: (1) subspherical, composite melt inclusions containing apatite, fayalite and magnetite, which indicate a magmatic origin; (2) two assemblages of primary fluid inclusions and, (3) six assemblages of secondary fluid inclusions (Borrok et al., 1998). The presence of fluid inclu- sions possibly relates to late stage "fluorine-overprinting" during the evolution of the system. The structurally controlled mineralization took place shortly after pipe emplacement, with the pipe acting as a preferential channel for fluids. Fluorite precipitation was induced by mixing with a second fluid or meteoric waters, or changes in $\mathrm{pH}$. The hydrothermal overprint is also supported by the presence of ferroactinolite ( $\mathrm{Fe \#}>0.9)$ in the Vergenoeg deposit (Borrok et al., 1998), as experiments show that such ferroactinolite is not stable at magmatic temperatures (Lledo and Jenkins, 2008). Thus we suggest that the "excess fluorine" is the result of a final stage of evolution of the magmatic (to late-stage magmatic-hydrothermal) system that formed the pipe-filling originally. The isotopic signature of fluorite in the Vergenoeg deposit also supports the suggestion of late magmatic fluids transporting fluorine (Kinnaird et al., 2004).

\subsection{Implications for Kiruna-type deposits}

The phase relations obtained in this experimental study have general implications for the genesis of magnetite deposits of the Kiruna type.

(1) Our experiments indicate that silicate liquid immiscibility plays a role in the formation of Kiruna-type deposits as emphasized in several studies (e.g., Nystrom and Henriquez, 1994; Travisany et al., 1995; Naslund et al., 2002; Henríquez et al., 2003; Chen et al., 2010), in contrast to the magmatichydrothermal models (Rhodes and Oreskes, 1995, 1999; Haynes et al., 1995; Barton and Johnson, 1996, 2004; Rhodes and Oreskes, 1999; Haynes, 2000; Sillitoe and Burrows, 2002). However, the nearly pure "oxide melt" often assumed in these magmatic models cannot be confirmed by our data. 
Table 4

Microprobe analyses (wt.\%) of major oxides in experimental glasses.

\begin{tabular}{|c|c|c|c|c|c|c|c|c|c|c|c|c|c|c|c|c|}
\hline Sample & $\mathrm{SiO}_{2}$ & $\mathrm{TiO}_{2}$ & $\mathrm{Al}_{2} \mathrm{O}_{3}$ & eOtot & $\operatorname{InO}$ & $\mathrm{IgO}$ & $\mathrm{CaO}$ & $\mathrm{Na}_{2} \mathrm{O}$ & $\mathrm{K}_{2} \mathrm{O}$ & $\mathrm{F}_{2} \mathrm{O}_{-1}$ & $\mathrm{P}_{2} \mathrm{O}_{5}$ & $\mathrm{H}_{2} \mathrm{O}$ & $\mathrm{F}$ & Total & $\mathrm{Mg \#}$ & $n^{\mathrm{a}}$ \\
\hline A0a Si-glass & 65.24 & .06 & 8.63 & .45 & & (5 & 4.37 & 1.86 & 41 & 1.70 & & & & & & \\
\hline A0a Fe-glass & & 13 & & & & & & & & & & & & & & \\
\hline A0b glass & 53.92 & 20 & 42 & & & & & 5 & & 4 & & 00 & 0 & & 2 & \\
\hline A0c Si-glass & 65.84 & 10 & 8.79 & & & 52 & 4.29 & .91 & 16 & 1.45 & & 00 & .51 & & & \\
\hline A0c Fe-glass & 49.48 & 10 & .04 & 5.46 & & 33 & 10.64 & 1.57 & .82 & 2.60 & & 0.80 & .50 & & .59 & \\
\hline A5a glass & 67.23 & 10 & .75 & 77 & 27 & 48 & 4.37 & 1.63 & 36 & 1.74 & & 4.50 & 3.01 & 00.7 & 1.32 & 1 \\
\hline A5b glass & 55.08 & 10 & 7.6 & 7.32 & 0.34 & 0.48 & 6.09 & 1.67 & 3.62 & 2.32 & & 4.10 & 4.01 & 98.7 & .75 & \\
\hline B0a glass & 60.69 & .19 & 8.68 & 6.15 & 0.34 & 0.56 & 4.75 & 2.02 & 4.37 & 1.73 & & & 2.99 & 100.8 & 5.87 & \\
\hline B0b Si-glass & 67.44 & 10 & 9.70 & & & 3 & 4.26 & 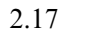 & .56 & 1.46 & & 0.60 & .53 & & & 5 \\
\hline B0t & & 26 & 0 & & & & & & & & & & .64 & & & 6 \\
\hline ss & & 10 & & & & & & & & & & & & & & 6 \\
\hline $\mathrm{CO}_{0}$ & 44.53 & 10 & 34 & & & & & & & & & & 36 & & & 5 \\
\hline ss & 69.38 & 40 & & & & & & & & & & & & & & \\
\hline & 70.29 & 48 & 31 & & & & & & 9 & & & & & & & \\
\hline & 77 & 56 & & & & & & & & & & & & & & \\
\hline & & 71 & 9 & & & & & & 0 & & & & 8 & & & \\
\hline D6b & 72.83 & .56 & 8.91 & & & & & & & & & 5 & & & 4 & \\
\hline $\mathrm{E} 2 \mathrm{a}$ & 83 & .34 & & & & & & & & & & & 2 & & 2 & \\
\hline & 89 & .25 & & & & & & & & & & & 2 & & & \\
\hline & & 34 & & & & & & & & & & & 1 & & & \\
\hline & 1 & 89 & 9 & & & & & & & & & & 9 & & & \\
\hline & & 95 & & & & & & & & & & & & & & \\
\hline & 71.32 & 0.78 & & & & & & & & & & & 1.70 & & & \\
\hline & & 0.36 & & & & & & & & & & & 2.42 & & & 8 \\
\hline & & 0.83 & 0.51 & & & & & & & & & & 3.84 & & & 9 \\
\hline G0b & 40.95 & 1.47 & 5.12 & & & & & & & & & & 5.66 & & 4. & 8 \\
\hline & & 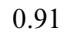 & & & & & & & & & & & 4 & & & 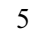 \\
\hline -glass & 41.40 & 50 & 56 & & & & & & & & & & 6.02 & & 5.55 & 5 \\
\hline $\mathrm{H} 0$ & 59.14 & .91 & 8.34 & 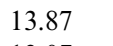 & & 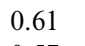 & 4. & 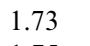 & 3 & 2. & 0 & & 4.10 & 1 & 7.34 & 6 \\
\hline & 59.28 & 1.17 & 54 & 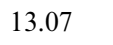 & 0.33 & 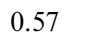 & 4 & 1. & 3 & 2. & 0 & $\mathrm{n}$. & 3.48 & & 7.28 & \\
\hline H0c Si-glass & 66.66 & 1.10 & 9.82 & & & 0.49 & & 2.20 & 4.20 & 1.92 & 0.16 & n.d. & 3.32 & 100.95 & 8.42 & \\
\hline H0c Fe-glass & 48.59 & 2.13 & 7.01 & 20.10 & & & 11.73 & 1.34 & & & & n.d. & 6.45 & & 10.64 & \\
\hline I0a & 75.06 & 0.28 & 11.59 & & & 0.41 & & 1.90 & 5.04 & 1.11 & 0.13 & n.d. & 1.92 & 99.20 & 20.92 & 9 \\
\hline $\mathrm{I} 0 \mathrm{~b}$ & 66.74 & .55 & 10.21 & & & & & 1.9 & & 2.0 & & & 3.49 & & 16.18 & 9 \\
\hline $\mathrm{J} 0 \mathrm{~h}$ & & . & & & & & & & & & & & 5.90 & & & \\
\hline & & 0.4 & & & & & & & & & & & & & & 8 \\
\hline I0c Fe-glass & & 1.3 & & & & & & & & & & & 4 & & & \\
\hline J6a & 62.87 & 0.87 & 9.27 & 9.39 & 0.28 & 0.62 & 4.96 & 1.98 & 3.80 & 2.11 & 0.18 & 5.42 & 3.65 & 99.49 & 10.62 & \\
\hline $\mathrm{J} 6 \mathrm{~b}$ & 62.60 & 0.90 & 9.20 & 9.75 & 0.28 & 0.63 & 5.15 & 1.46 & 3.55 & 2.17 & 0.18 & 5.4 & 3.75 & 101.31 & 10.42 & \\
\hline $\mathrm{J} 6 \mathrm{c}$ & 62.94 & 0.76 & 9.28 & 6.58 & 0.32 & 0.55 & 5.46 & 1.94 & 3.78 & 2.28 & 0.20 & 5.42 & 3.94 & 101.76 & 13.08 & 30 \\
\hline
\end{tabular}

n.d. $=$ not determined.

${ }^{\text {a }}$ Number of microprobe analyses.

b The water content was analyzed by FTIR, following the method described in Almeev et al. (2012). F was also recalculated to $\mathrm{F}_{2} \mathrm{O}_{-1}$ for compositional balance, $\mathrm{F}_{2} \mathrm{O}_{-1}\left(1 \% \mathrm{~F}_{2} \mathrm{O}_{-1}=1.73 \% \mathrm{~F}\right)$.

Although high-grade iron-rich melts can be produced experimentally in some simple systems (Weidner, 1982; Bogaerts and Schmidt, 2006; Lester et al., 2013), it is not observed in multi-component systems and the most Fe-rich liquid observed in this study contains $\sim 36$ wt. $\% \mathrm{FeO}_{\text {tot }}$. Accordingly, the massive iron ores may rather represent cumulates that crystallized from a Fe-rich immiscible melt.

(2) Enrichment of fluorine in residual melts is a favorable condition for liquid immiscibility. This is consistent with the experiments of Lester et al. (2013), which showed that additions of fluorine at $2 \mathrm{kbars}$ increases the $\mathrm{T}-\mathrm{X}$ (chemical composition) range of the miscibility gap in the system $\mathrm{K}_{2} \mathrm{O}-\mathrm{FeO}-\mathrm{Fe}_{2} \mathrm{O}_{3}-$
$\mathrm{Al}_{2} \mathrm{O}_{3}-\mathrm{SiO}_{2}$. In addition, the reduction in melt viscosity produced by the presence of fluorine, especially if the systems are water-poor (Baker and Vaillancourt, 1995; Bartels et al., 2013), favors the efficient separation of conjugate liquids by density, an important component of the immiscible petrogenetic model for the Kiruna ore deposit type. Moreover, most Kiruna-type deposits are enriched both in fluorine and phosphorous. Many experiments have shown that phosphorous promotes liquid immiscibility (Watson, 1976; Ryerson and Hess, 1978; Visser and Koster van Groos, 1979; Bogaerts and Schmidt, 2006; Charlier and Grove, 2012), by: (1) enhancing iron enrichment during differentiation 
because it destabilizes magnetite; (2) depressing the liquidus temperature, and expanding the two-liquid field. As stated above, fluorine can increase the activity of $\mathrm{FeO}$ in the melt and depress the liquidus temperature. Thus a F-P-rich system is a favorable magmatic environment for the development of liquid immiscibility.

(3) The presence of water is not favorable for the development of silicate liquid immiscibility because it strongly increases oxygen fugacity, which promotes magnetite crystallization. Water thus is a limiting factor for a significant $\mathrm{Fe}$ enrichment during differentiation and inhibits the development of immiscibility.

\section{CONCLUSIONS}

Experimental results indicate that the Vergenoeg pipe may have formed from a stratified magma chamber hosting two immiscible silicate melts. Immiscibility in the shallow magma chamber was potentially induced by high fluorine concentrations in the magma, relatively waterpoor conditions and low oxygen fugacity. Fractional crystallization of magnetite, fayalite and possibly fluorite led to the formation of a crystal mush in the lower part of the magma chamber. The extremely high fluorite content of the Vergenoeg pipe is, in part, attributed to hydrothermal fluids, with the pipe acting as a preferential channel for fluid migration.

\section{ACKNOWLEDGMENTS}

Constructive reviews and suggestions by Dr. Adam Simon and an anonymous reviewer helped to improve the manuscript. V. Honour is thanked for careful editing of the manuscript. André Stechern, Robert Balzer, and Julian Feige are thanked for their aid during the IHPV experiments and sample preparation, respectively. We also thank Renat Almeev and Chao Zhang for their assistance with microprobe analyses. TH acknowledges support by a Marie Curie Individual Fellowship within the Horizon 2020 - Research and Innovation Framework Programme (656923), China Nature Foundation of Sciences (41502052) and the "Fundamental Research Funds for the Central Universities (2652015054)". BC is a Research Associate of the Belgian Fund for Scientific Research-FNRS. ON was supported by a Marie-Curie Intra European Fellowship and a FNRS postdoctoral fellowship.

\section{APPENDIX A. SUPPLEMENTARY DATA}

Supplementary data associated with this article can be found, in the online version, at http://dx.doi.org/10.1016/ j.gca.2017.01.025.

\section{REFERENCES}

Almeev R. R., Bolte T., Nash B. P., Holtz F., Erdmann M. and Cathey H. E. (2012) High-temperature, low- $\mathrm{H}_{2} \mathrm{O}$ silicic magmas of the Yellowstone hotspot: an experimental study of rhyolite from the Bruneau-Jarbidge Eruptive Center, Central Snake River Plain, USA. J. Petrol. 53, 1837-1866.
Baker D. R. and Vaillancourt J. (1995) The low viscosities of F $+\mathrm{H}_{2} \mathrm{O}$-bearing granitic melts and implications for melt extraction and transport. Earth Planet. Sci. Lett. 132, 199-211.

Barnes S. J. and Maier W. D. (2002) Platinum-group elements and microstructures of normal Merensky Reef from Impala platinum mines, Bushveld Complex. J. Petrol. 43, 103-128.

Bartels A., Behrens H., Holtz F., Schmidt B. C., Fechtelkord M., Knipping J., Crede L., Baasner A. and Pukallus N. (2013) The effect of fluorine boron and phosphorus on the viscosity of pegmatitic liquids. Chem. Geol. 346, 184-198.

Barton M. D. and Johnson D. A. (1996) Evaporitic-source model for igneous-related $\mathrm{Fe}$ oxide-( $\mathrm{REE}-\mathrm{Cu}-\mathrm{Au}-\mathrm{U})$ mineralization. Geology 24, 259-262.

Barton M. D. and Johnson D. A. (2004). , pp. 112-116. Footprints of $\mathrm{Fe}$-oxide $(-\mathrm{Cu}-\mathrm{Au})$ systems.

Berndt J., Liebske C., Holtz F., Freise M., Nowak M., Ziegenbein D., Hurkuck W. and Koepke J. (2002) A combined rapidquench and $\mathrm{H}_{2}$-membrane setup for internally heated pressure vessels: Description and application for water solubility in basaltic melts. Am. Mineral. 87, 1717-1726.

Berndt J., Koepke J. and Holtz F. (2005) An experimental investigation of the influence of water and oxygen fugacity on differentiation of MORB at $200 \mathrm{MPa}$. J. Petrol. 46, 135-167.

Bilenker L., Simon A. C., Reich M., Lundstrom C., Bindeman I. and Munizaga R. (2016) Fe-O stable isotope pairs elucidate a high-temperature origin of Chilean iron oxide-apatite deposits. Geochim. Cosmochim. Acta 177, 94-104.

Bogaerts M. and Schmidt M. W. (2006) Experiments on silicate melt immiscibility in the system $\mathrm{Fe}_{2} \mathrm{SiO}_{4}-\mathrm{KAlSi}_{3} \mathrm{O}_{8}-\mathrm{SiO}_{2}$ $\mathrm{CaO}-\mathrm{MgO}-\mathrm{TiO}_{2}-\mathrm{P}_{2} \mathrm{O}_{5}$ and implications for natural magmas. Contrib. Mineral. Petrol. 152, 257-274.

Borrok D. M., Kelser S. E., Boer R. H. and Essene E. J. (1998) The Vergenoeg magnetite-fluorite deposit, South Africa; support for a hydrothermal model for massive iron oxide deposits. Econ. Geol. 93, 564-586.

Botcharnikov R. E., Koepke J., Holtz F., McCammon C. and Wilke M. (2005) The effect of water activity on the oxidation and structural state of $\mathrm{Fe}$ in a ferro-basaltic melt. Geochim. Cosmochim. Acta 69, 5071-5085.

Botcharnikov R. E., Almeev R. R., Koepke J. and Holtz F. (2008) Phase relations and liquid lines of descent in hydrous ferrobasalt-implications for the Skaergaard intrusion and Columbia River flood basalts. J. Petrol. 49, 1687-1727.

Buchanan P. C., Koeberl C. and Reimold W. U. (1999) Petrogenesis of the Dullstroom formation, Bushveld magmatic province, South Africa. Contrib. Mineral. Petrol. 137, 133-146.

Buchanan P., Reimold W., Koeberl C. and Kruger F. (2002) Geochemistry of intermediate to siliceous volcanic rocks of the Rooiberg Group, Bushveld magmatic province, South Africa. Contrib. Mineral. Petrol. 144, 131-143.

Buchanan P. C., Reimold W. U., Koeberl C. and Kruger F. J. (2004) $\mathrm{Rb}-\mathrm{Sr}$ and $\mathrm{Sm}-\mathrm{Nd}$ isotopic compositions of the Rooiberg Group, South Africa: early Bushveld-related volcanism. Lithos 75, 373-388.

Buddington A. F. and Lindsley D. H. (1964) Iron-titanium oxide minerals and synthetic equivalents. J. Petrol. 5, 310-357.

Burnham C. W. (1994) Development of the Burnham model for prediction of $\mathrm{H}_{2} \mathrm{O}$ solubility in magmas. Miner. Soc. Am. Rev. Mineral. 30, 123-129.

Charlier B. and Grove T. L. (2012) Experiments on liquid immiscibility along tholeiitic liquid lines of descent. Contrib. Mineral. Petrol. 164, 27-44.

Chen H., Clark A. H. and Kyser T. K. (2010) The Marcona magnetite deposit, Ica, South-Central Peru: a product of hydrous, iron oxide-rich melts? Econ. Geol. 105, 1441-1456. 
Childress T. M., Simon A. C., Day W. C., Lundstrom C. C. and Bindeman I. N. (2016) Iron and oxygen isotope signatures of the Pea Ridge and Pilot Knob magnetite-apatite deposits, southeast Missouri, USA. Econ. Geol. 111, 2033-2044.

Crocker I. T. (1985) Volcanogenic fluorite-hematite deposits and associated pyroclastic rock suite at Vergenoeg, Bushveld Complex. Econ. Geol. 80, 1181-1200.

Crocker I. T., Eales H. V. and Ehlers D. I. (2001) Fluorite, Cassiterite and Sulphide Deposits Associated with the Acid Rocks of the Bushveld Complex. Memoir of the Council for Geosciences, South Africa, p. 151.

Dare S. A., Barnes S. J., Beaudoin G., Méric J., Boutroy E. and Potvin-Doucet C. (2014a) Trace elements in magnetite as petrogenetic indicators. Miner. Deposita 49, 785-796.

Dare S. A., Barnes S. J. and Beaudoin G. (2014b) Did the massive magnetite "lava flows" of El Laco (Chile) form by magmatic or hydrothermal processes? New constraints from magnetite composition by LA-ICP-MS. Miner. Deposita 50, 607-617.

Devine J. D., Gardner J. E., Brack H. P., Layne G. D. and Rutherford M. J. (1995) Comparison of microanalytical methods for estimating $\mathrm{H}_{2} \mathrm{O}$ contents of silicic volcanic glasses. Am. Mineral. 80, 319-328.

Dill H. (2010) The "chessboard" classification scheme of mineral deposits: mineralogy and geology from aluminum to zirconium. Earth-Sci. Rev. 100, 1-420.

Dingwell D. B. (1985) The structure and properties of fluorine-rich silicate melts: implications for granite petrogenesis. In GraniteRelated Mineral Deposits: Geology, Petrogenesis and Tectonic Setting. Canadian Institute of Mining, Metallurgy and Petroleum, Halifax, NS, pp. 72-81.

Dixon S. and Rutherford M. J. (1979) Plagiogranites as late-stage immiscible liquids in ophiolite and mid-ocean ridge suites: an experimental study. Earth Planet. Sci. Lett. 45, 45-60.

Eriksson P. G., Hattingh P. J. and Altermann W. (1995) An overview of the Transvaal sequence and Bushveld Complex, South Africa. Miner. Deposita 30, 98-111.

Filiberto J., Wood J., Dasgupta R., Shimizu N., Le L. and Treiman A. H. (2012) Effect of fluorine on near-liquidus phase equilibria of an Fe-Mg rich basalt. Chem. Geol. 312-313, 118-126.

Fourie P. J. (2000) The Vergenoeg fayalite iron oxide fluorite deposit, South Africa: some new aspects. In Hydrothermal Iron Oxide Copper-Gold and Related Deposits a Global Perspective (ed. T. M. Porter). Australian Mineral Foundation, Adelaide, pp. 309-320.

Frietsch R. (1978) On the magmatic origin of iron ores of the Kiruna type. Econ. Geol. 73, 478-485.

Giordano D., Romano C., Dingwell D. B., Poe B. and Behrens H. (2004) The combined effects of water and fluorine on the viscosity of silicic magmas. Geochim. Cosmochim. Acta 68, 5159-5168.

Gleason J. D., Marikos M. A., Barton M. D. and Johnson D. A. (2000) Neodymium isotopic study of rare earth element sources and mobility in hydrothermal Fe oxide (Fe-P-REE) systems. Geochim. Cosmochim. Acta 64, 1059-1068.

Goff B. H., Weinberg R., Groves D. I., Vielreicher N. M. and Fourie P. J. (2004) The giant Vergenoeg fluorite deposit in a magnetite-fluorite-fayalite REE pipe: a hydrothermally-altered carbonatite-related pegmatoid? Mineral. Petrol. 80, 173-199.

Graupner T., Mühlbach C., Schwarz-Schampera U., Henjes-Kunst F., Melcher F. and Terblanche H. (2015) Mineralogy of highfield-strength elements ( $\mathrm{Y}, \mathrm{Nb}, \mathrm{REE})$ in the world-class Vergenoeg fluorite deposit, South Africa. Ore Geol. Rev. 64, 583-601.

Harlov D. E., Andersson U. B., Förster H. J., Nyström J. O., Dulski P. and Broman C. (2002) Apatite-monazite relations in the Kiirunavaara magnetite-apatite ore, northern Sweden. Chem. Geol. 191, 47-72.

Harlov D. E., Meighan C. J., Kerr I. D. and Samson I. M. (2016) Mineralogy, chemistry, and fluid-aided evolution of the Pea Ridge Fe oxide-(Y + REE) deposit, southeast Missouri, USA. Econ. Geol. 111, 1963-1984.

Hatton C. J. and Schweitzer J. K. (1995) Evidence for synchronous extrusive and intrusive Bushveld magmatism. J. Afr. Earth Sci. 21, 579-594.

Haynes D. W. (2000) Iron oxide copper (-gold) deposits: their position in the ore deposit spectrum and modes of origin. In Hydrothermal Iron Oxide Copper-Gold \& related deposits. A global perspective (ed. T. M. Porter), pp. 71-90.

Haynes D. W., Cross K. C., Bills R. T. and Reed M. H. (1995) Olympic Dam ore genesis; a fluid-mixing model. Econ. Geol. 90, 281-307.

Henríquez F., Naslund H. R., Nyström J. O., Vivallo W., Aguirre R., Dobbs F. M. and Lledó H. (2003) New field evidence bearing on the origin of the El Laco magnetite deposit, northern Chile - a discussion. Econ. Geol. 98, 1497-1500.

Hildebrand R. S. (1986) Kiruna-type deposits; their origin and relationship to intermediate subvolcanic plutons in the Great Bear magmatic zone, Northwest Canada. Econ. Geol. 81, 640659.

Hitzman M. W. (2000) Iron oxide-Cu-Au deposits: what, where, when, and why. In Hydrothermal Iron Oxide Copper-gold \& Related Deposits: A Global Perspective, vol. 2 (ed. T. M. Porter). PGC Publishing, Adelaide, Australia, pp. 9-25.

Hitzman M. W., Oreskes N. and Einaudi M. T. (1992) Geological characteristics and tectonic setting of proterozoic iron oxide (Cu-U-Au-REE) deposits. Precam. Res. 58, 241-287.

Jonsson E., Troll V. R., Högdahl K., Harris C., Weis F., Nilsson K. P. and Skelton A. (2013) Magmatic origin of giant 'Kirunatype' apatite-iron-oxide ores in Central Sweden. Sci. Rep. 3.

Jonsson E., Harlov D. E., Majka J., Högdahl K. and PerssonNilsson K. (2016) Fluorapatite-monazite-allanite relations in the Grängesberg apatite-iron oxide ore district, Bergslagen, Sweden. Am. Mineral. 101(8), 1769-1782.

Kinnaird J. A., Kruger F. J. and Cawthorn R. G. (2004) Rb-Sr and $\mathrm{Nd}-\mathrm{Sm}$ isotopes in fluorite related to the granites of the Bushveld Complex. S. Afr. J. Geol. 107, 413-430.

Kleemann G. J. and Twist D. (1989) The compositionally-zoned sheet-like granite pluton of the Bushveld Complex: evidence bearing on the nature of A-type magmatism. J. Petrol. 30, $1383-1414$.

Knipping J. L., Bilenker L. D., Simon A. C., Reich M., Barra F., Deditius A. P., Wälle M., Heinrich C. A., Holtz F. and Munizaga R. (2015a) Trace elements in magnetite from massive iron oxide-apatite deposits indicate a combined formation by igneous and magmatic-hydrothermal processes. Geochim. Cosmochim. Acta 171, 15-38.

Knipping J. L., Bilenker L. D., Simon A. C., Reich M., Barra F., Deditius A. P., Lundstrom C., Bindeman I. and Munizaga R. (2015b) Giant Kiruna-type deposits form by efficient flotation of magmatic magnetite suspensions. Geology 43, 591-594.

Lester G. W., Clark A. H., Kyser T. K. and Naslund H. R. (2013) Experiments on liquid immiscibility in silicate melts with $\mathrm{H}_{2} \mathrm{O}$, $\mathrm{P}, \mathrm{S}, \mathrm{F}$ and $\mathrm{Cl}$ : implications for natural magmas. Contrib. Miner. Petrol. 166, 329-349.

Lledo H. L. and Jenkins D. M. (2008) Experimental investigation of the upper thermal stability of Mg-rich actinolite; implications for Kiruna-type iron deposits. J. Petrol. 49, 225-238.

Manning D. A. C. (1981) The effect of fluorine on liquidus phase relationships in the system Qz-Ab-Or with excess water at $1 \mathrm{~kb}$. Contrib. Miner. Petrol. 76, 206-215. 
Mathez E. A., VanTongeren J. A. and Schweitzer J. (2013) On the relationships between the Bushveld Complex and its felsic roof rocks, part 1: petrogenesis of Rooiberg and related felsites. Contrib. Miner. Petrol. 166, 435-449.

Naslund H. R. (1983) The effects of oxygen fugacity on liquid immiscibility in iron-bearing silicate melts. Am. J. Sci. 283, 1034-1059.

Naslund H. R., Henríquez F., Nyström J. O., Vivallo W. and Dobbs F. M. (2002) Magmatic iron ores and associated mineralization: Examples from the Chilean High Andes and Coastal Cordillera. In Hydrothermal iron oxide copper-gold and related deposits: A global perspective, vol. 2, pp. 207-226.

Nystrom J. O. and Henriquez F. (1994) Magmatic features of iron ores of the Kiruna type in Chile and Sweden: Ore textures and magnetite geochemistry. Econ. Geol. 89, 820-839.

Nyström J. O., Billström K., Henríquez F., Fallick A. E. and Naslund H. R. (2008) Oxygen isotope composition of magnetite in iron ores of the Kiruna type in Chile and Sweden. GFF 130, $177-188$.

Parak T. (1975) Kiruna iron ores are not "intrusive-magmatic ores of the Kiruna type". Econ. Geol. 70, 1242-1258.

Philpotts A. R. and Doyle C. D. (1983) Effect of magma oxidation state on the extent of silicate liquid immiscibility in a tholeiitic basalt. Am. J. Sci. 283, 967-986.

Rhodes A. L. and Oreskes N. (1995) Magnetite deposition at El Laco, Chile: implications for Fe-oxide formation in magmatichydrothermal systems. Giant ore deposits-II. Controls on the scale of orogenic magmatic-hydrothermal mineralization, $\mathrm{pp}$. 582-622.

Rhodes A. L. and Oreskes N. (1999) Oxygen isotope composition of magnetite deposits at El Laco, Chile: Evidence of formation from isotopically heavy fluids. Geology and Ore Deposits of the Central Andes, Brian J. Skinner, ed. Geol. Soc. Spec. Publ. 7, 333-351.

Ryerson F. J. and Hess P. C. (1978) Implications of liquid-liquid distribution coefficients to mineral-liquid partitioning. Geochim. Cosmochim. Acta 42, 921-932.

Schweitzer J. K. and Hatton C. J. (1995) Chemical alteration within the volcanic roof rocks of the Bushveld Complex. Econo. Geol. 90, 2218-2231.

Schweitzer J. K., Hatton C. J. and De Waal S. A. (1995) Economic potential of the Rooiberg Group: volcanic rocks in the floor and roof of the Bushveld Complex. Miner. Deposita 30, 168177.
Sillitoe R. H. and Burrows D. R. (2002) New field evidence bearing on the origin of the El Laco magnetite deposit, northern Chile. Econ. Geol. 97, 1101-1109.

Toplis M. J. and Carroll M. R. (1995) An experimental study of the influence of oxygen fugacity on Fe-Ti oxide stability, phase relations, and mineral-melt equilibria in ferro-basaltic systems. J. Petrol. 36, 1137-1170.

Tornos F., Velasco F. and Hanchar J. M. (2016) Iron-rich melts, magmatic magnetite, and superheated hydrothermal systems: The El Laco deposit, Chile. Geology 44, 427-430.

Travisany V., Henriquez F. and Nystrom J. O. (1995) Magnetite lava flows in the Pleito-Melon district of the Chilean iron belt. Econ. Geol. 99, 438-444.

Twist D. and French B. M. (1983) Voluminous acid volcanism in the Busheveld Complex: A review of the Rooiberg Felsite. Bull. Volcanol. 46, 225-242.

Velasco F., Tornos F. and Hanchar J. M. (2016) Immiscible ironand silica-rich melts and magnetite geochemistry at the El Laco volcano (northern Chile): Evidence for a magmatic origin for the magnetite deposits. Ore Geol. Rev. 79, 346-366.

Visser W. and Koster van Groos A. F. (1979) Effect of $\mathrm{P}_{2} \mathrm{O}_{5}$ and $\mathrm{TiO}_{2}$ on liquid-liquid equilibria in the system $\mathrm{K}_{2} \mathrm{O}-\mathrm{FeO}-\mathrm{Al}_{2} \mathrm{O}_{3}-$ $\mathrm{SiO}_{2}$. Am. J. Sci. 279, 970-988.

Watson E. B. (1976) Two-liquid partition coefficients: experimental data and geochemical implications. Contrib. Mineral. Petrol. 56, $119-134$.

Weidner J. R. (1982) Iron-oxide magmas Tn the svstem Fe-Co. Can. Miner. 20, 555-566.

Williams P. J., Barton M. D., Johnson D. A., Fontboté L., De Haller A., Mark G., Oliver N. H. S. and Marschik R. (2005) Iron oxide copper-gold deposits: Geology, space-time distribution, and possible modes of origin. Econ. Geol., 371-405 (100th Anniversary).

Zhang C., Koepke J., Wang L., Wolff P. E., Wilke S., Stechern A., Almeev R. and Holtz F. (2016) A practical method for accurate measurement of trace level fluorine in $\mathrm{Mg}$ - and Fe-bearing mineral and glass using electron probe microanalysis. Geostand. Geoanal. Res. http://dx.doi.org/10.1111/j.1751-908X.2015. 00390.x. 